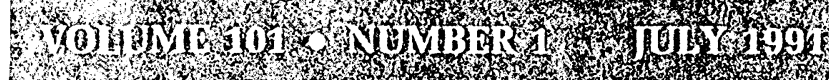

17.17,

H.7,

GASHR OIVI 
1 This Month in GASTROENTEROLOGY

\section{ALIMENTARY TRACT}

3 Sensitivity of the Gastric Mucosa to Acid and Duodenal Contents in Patients With Nonulcer Dyspepsia A.A. George, M. TSuChiYose, ANd C.P. DoOley

7 Phospholipid-and Neutral Lipid-Containing Organelles of Rat Gastroduodenal Mucous Cells Y.-C.J. KAO AND L.M. LICHTENBERGER

22 Acute Intestinal Injury Induced by Acetic Acid and Casein: Prevention by Intraluminal Misoprostol M.J.S. Miller, X.-J. Zhang, X. Gu, AND D.A. Clark

31 T-Lymphocyte Modulation of Intestinal Muscle Function in the Trichinella-Infected Rat

D.L. Vermillion, P.B. ERNST, AND S.M. COLlins

39 Use of Azathioprine or 6-Mercaptopurine in the Treatment of Crohn's Disease J.J. O'BRIEN, T.M. BAYLESS, AND J.A. BAYLESS

47 Localization of Endothelinlike Immunoreactivity and Endothelin Binding Sites in Human Colon H. INAGAKI, A.E. BISHOP, C. ESCRIG, J. WHARTON, T.G. AlLEN-MERSh, ANI J.M. POLAK

55 The Mechanism of Action of Peppermint Oil on Gastrointestinal Smooth Muscle J.M. HILLS AND P.I. AARONSON

66 Gastric Acid Secretion and Parietal Cell Mass: Effect of Sex Hormones

K.A. ADENIYI

70 Proliferation of Endocrine Cells in the Rat Stomach Caused by Drug-Induced Achlorhydria

R. EISSELE, B. ROßKOPF, H. KOOP, G. ADLER, ANI) R. ARNOLD

77 A Novel Enzyme Immunoassay for Serodiagnosis of Helicobacter pylori Infection

T. SUGIYAMA, K. IMAI, H. Yoshida, Y. TAKAYAMA, T. Yabana,

K. YокоTA, K. OGUMA, AND A. YACHI

84 The Effect of Elemental Diet on Intestinal Permeability and Inflammation in Crohn's Disease

K. Teahon, P. Smethurst, M. Pearson, A.J. Levi, AND I. BJARNASON

90 Lamina Propria Lymphocytes Are Derived From Circulating Cells That Lack the Leu-8 Lymph Node Homing Receptor M. BERG, Y. MurakaWA, D. CAMERINI, AND S.P. James

100 Effect of Enteric Pacing on Intestinal Motility and Hormone Secretion in Dogs With Short Bowel

S.B. REISER, V. SCHUSDZIARRA, E. BOLLSCHWEILER,

A.H. HÖLSCHER, AND J.R. SIEWERT

107 Scintigraphic Measurement of Regional Gut Transit in Idiopathic Constipation

T. Stivland, M. Camilleri, M. Vassallo, M. Proano, D. Rath, M. Brown, G. Thomforde, J. Pemberton, and S. Phillips

116 Lipase and Pepsin Activity in the Gastric Mucosa of Infants, Children, and Adults J. DiPalma, C. Kirk, M. Hamosh, A.R. Colon, S.B. Benjamin, AND P. HAMOSH
122 Epidemiology of Inflammatory Bowel Disease Among U.S. Military Veterans

A. SONNENBERG AND I.H. WASSERMAN

131 Basophil-Bound and Serum Immunoglobulin E Directed Against Helicobacter pylori in Patients With Chronic Gastritis

A. Aceti, D. Celestino, M. Caferro, V. Casale, F. Citarda, E.M. Conti, A. Grassi, A. Grilli, A. Pennica, F. Sciarretta, O. LeRI, F. AMEGLIO, AND A. SEBASTIANI

138 Pharmacokinetics of Oral and Intravenous Omeprazole in Patients With the Zollinger-Ellison Syndrome R. Vinayek, M. Amantea, P.N. Maton, H. Frucht, J.D. GARDNER, AND R.T. JENSEN

148 Long-Term Prognosis After Partial Gastrectomy for Benign Conditions

A.C. Tersmette, G.J.A. Offerhaus, F.M. Giardiello, R. Brand, K.W.F. TERSMETTE, G.N.J. TYTGAT, AND J.P. VANDENBROUCKE

154 Genetic Characterization of the APC Locus Involved in Familial Adenomatous Polyposis

S. Olschwang, B. Weiffenbach, P. Laurent-Puig, T. Melot, A. Vassal, K. Falls, R.J. Salmon, R. Parc, L. Strong, Y. NAKAMURA, L. HERRERA, AND G. THOMAS

161 Induction of Heat Shock Proteins and Their Implication in Protection Against Ethanol-Induced Damage in Cultured Guinea Pig Gastric Mucosal Cells K. Nakamura, K. Rokutan, N. Marul, A. Aoike, and K. Kawal

167 Positive Serum Antibody and Negative Tissue Staining for Helicobacter pylori in Subjects With Atrophic Body Gastritis

W.E. Karnes, Jr., I.M. Samloff, M. SiUral.A, M. KekKI, P. SIPPONEN, S.W.R. KIM, AND J.H. WALSH

175 Reproducibility of Measurements of Trace Gas Concentrations in Expired Air A. STROCCHI, C. Ellis, AND M.D. LeVITt

\section{LIVER, PANCREAS, AND BILIARY TRACT}

180 Increased Paracellular Permeability in Intrahepatic Cholestasis Induced by Carmustine (BCNU) in Rats H. KRELL, H. FROMM, AND R.E. LARSON

189 Cost-Effectiveness of Extracorporeal Shock-Wave Lithotripsy Versus Cholecystectomy for Symptomatic Gallstones

E.B. BAss, E.P. Steinberg, H.A. PitT, G.P. SABA, K.D. Lillemoe, D.R. KAFONEK, T.R. GADACZ, T.A. GORDON, AND G.F. ANDERSON

200 Distribution of the VLA Family of Integrins in Normal and Pathological Human Liver Tissue R. VOLPES, J.J. VAN DEN OORD, AND V.J. DESMET

207 The Bentiromide Test Using Plasma p-Aminobenzoic Acid for Diagnosing Pancreatic Insufficiency in Young Children D. LAUFER, G. Cleghorn, G. FORSTNER, L. Ellis, G. KOREN, AND P. DURIE

214 Factors Affecting the Measurement of Cholesterol Nucleation in Human Gallbladder and Duodenal Bile J.W. MARKS, P. BROOMFIELD, G.G. BONORRIS, AND L.J. SCHOENFIELD 
220 Secretagogue Response of Azaserine-Induced Rat Pancreatic Acinar Tumors in Vivo

K.-H. HeRZIG, W. CREuTZFELdT, AND U.R. FöLSCH

228 Impaired Hepatic Handling and Processing of Lysophosphatidylcholine in Rats With Liver Cirrhosis M. Angelico, D. Alvaro, A. Cantafora, R. Masella, E. Gaudio, C. Gandin, S.G. Corradini, F. Ariosto, O. Riggio, AND L. CAPOCACCIA

\section{CASE REPORTS}

238 Growth in Adulthood After Liver Transplantation for Glycogen Storage Disease Type I B.S. KIRSCHNER, A.L. BAKER, AND F.K. THORP

242 Development of Sustained Achlorhydria in a Patient With the Zollinger-Ellison Syndrome Treated With Omeprazole J.L. Griffith, O.W. Cummings, AND B.I. HiRschowitZ

247 Cytomegalovirus Infection of the Appendix in a Patient With the Acquired Immunodeficiency Syndrome S. VAlERdiZ-CASASOla AND F.J. PARDO-MindaN

250 Ursodeoxycholic Acid for the Treatment of Home Parenteral Nutrition-Associated Cholestasis K.D. LINDOR AND J. BURNES

\section{CLINICAL CHALLENGES}

254 Exacerbation of Ulcerative Colitis D.J. HERMENS AND P.B. MINER, JR.

\section{SELECTED SUMMARIES}

263 Treatment of Bleeding Arteriovenous Malformations With Oral Contraceptives: Safe Sex?
264 How Enterocytes Stick and What They Stick To

266 Superficial Esophageal Carcinoma: Will Early Detection Help?

267 Evidence for a Direct Hepatoprotective Action of Ursodeoxycholic Acid in Primary Human Hepatocytes

268 Toward a Treatment for Anorexia and Cachexia in Patients With Cancer

271 BOOK REVIEWS

\section{CORRESPONDENCE}

274 24-Hour Intragastric Acidity and Plasma Gastrin After Omeprazole Treatment and After Proximal Gastric Vagotomy in Duodenal Ulcer Patients

274 Persisting Benzodiazepine Metabolites Responsible for the Reaction to the Benzodiazepine Antagonist Flumazenil in Patients With Hepatic Encephalopathy

275 Treatment of Cholesterol Gallstone Patients With Ursodeoxycholic Acid

276 'Abstract Creep' in GASTROENTEROLOGY

276 Pancreatic Exocrine Secretion in Acute Experimental Pancreatitis

278 Efficacy of Dextran-70 As a Substitute for Albumin

280 Calcium Carbonate Solubility in Human Common Duct Bile: Calcium Carbonate Precipitation in Gallstones

281 Acute Necrotizing Esophagitis: Another Case

283 NOTICES

NO. 2, AUGUST 1991

285 This Month in GASTROENTEROLOGY

\section{ALIMENTARY TRACT}

287 The Parietal Cell Autoantibodies Recognized in Neonatal Thymectomy-Induced Murine Gastritis Are the $\alpha$ and $\beta$ Subunits of the Gastric Proton Pump C.M. Jones, J.M. Callaghan, P.A. Gleeson, Y. Mori, T. MASUDA, AND B.-H. TOH

295 Microvascular Permeability Increases Early in the Course of Acid-Induced Esophageal Injury

F.G. ZIJLSTRA, T.T. HYNNA-LIEPERT, P.K. DiNDA, I.T. BECK, AND W.G. PATERSON

303 Establishment and Characterization of a Human Carcinoid in Nude Mice and Effect of Various Agents on Tumor Growth B.M. Evers, C.M. TOWNSEnd, JR., J.R. UpP, E. Allen, S.C. Hurlbut, S.W. Kim, S. Rajaraman, P. Singh, J.C. Reubi, AND J.C. THOMPSON

312 Posttranslational Cleavage of Rat Intestinal Lactase Occurs at the Luminal Side of the Brush Border Membrane K.-Y. YEH, M. YEH, P.-C. PAN, AND P.R. HOLT
319 Effects of Vibrio cholerae Recombinant Strains on Rabbit Ileum In Vivo C.D. Lind, R.H. DAvis, R.L. GUERRANT, J.B. KaPER, AND J.R. MATHIAS

325 Effect of Neuropeptide $Y$ on Jejunal Water and Ion Transport in Humans

U. Holzer-Petsche, W. Petritsch, T. Hinterleitner, A. Eherer. G. SPERK, AND G.J. KREJS

331 Mechanism of Short-Chain Fatty Acid Uptake by Apical Membrane Vesicles of Rat Distal Colon N. Mascolo, V.M. RaJENDRAN, AND H.J. BindER

339 Developmental Characteristics of the Kitten Antrum A.C. HILLEMEIER, K.N. BITAR, AND P. BIANCANI

344 Abnormal Esophageal Motility B.T. Massey, W.J. Dodds, W.J. Hogan, J.G. Brasseur, AND J.F. HELM

355 Regional Esophageal Distribution and Clearance of Refluxed Gastric Acid R. SHAKER, W.J. DODDS, J.F. HELM, M.K. KERN, AND W.J. HOGAN

360 Intestinal Absorption of Fructose in the Rat T. FUISAWA, J. RIBY, AND N. KRETCHMER 
368 Long-Term Survival Analysis in Hereditary Hemochromatosis

P.C. AdAMS, M. SPEECHLEY, AND A.E. KeRTESZ

373 Variation of Muscle Tone in the Human Colon C.J. Steadman, S.F. Phillips, M. Camilleri, A.C. Haddad, AND R.B. HANSON

382 Premicellar Taurocholate Enhances Ferrous Iron Uptake From All Regions of Rat Small Intestine A.J. Sanyal, M.L. Shiffman, J.I. HirsCh, ANd E.W. Moore

390 T-Lymphocyte Dysfunctions Occurring Together With Apical Gut Epithelial Cell Autoantibodies J.M. Martín-Villa, J.R. Regueiro, D. de Juan, P. PÉrez-Aciego, M. Pérez Blas, J. Manzanares, G. Varela, AND A. ARNAIZ-VILLENA

398 Ion Transport Abnormalities in Rectal Suction Biopsies From Children With Cystic Fibrosis H.J. VEeZe, M. SinAASAPPEl, J. BIJMAN, J. BOUQUET, AND H.R. DE JONGE

404 Aspirin Induces Morphological Transformation to the Secretory State in Isolated Rabbit Parietal Cells U.K. MURTHY AND R.A. LEVINE

410 Circadian Rhythm of Cellular Proliferation in the Human Rectal Mucosa K.N. BUCHI, J.G. MOORE, W.J.M. HRUSHESKY, R.B. SOTHERN, AND N.H. RUBIN

416 Sensory Neurons Signal for an Increase in Rat Gastric Mucosal Blood Flow in the Face of Pending Acid Injury P. Holzer, E.H. Livingston, AND P.H. GuTH

424 Presence of Atrial Natriuretic Factor Prohormone in Enterochromaffin Cells of the Human Large Intestine A.L. Gerbes, W. Nathrath, M. Cantin, and H. Denecke

430 Increased $\mathrm{Na}^{+}-\mathrm{H}^{+}$Exchange in Jejunal Brush Border Membrane Vesicles of Spontaneously Hypertensive Rats S. ACRA AND F.K. GHISHAN

437 Helicobacter pylori Infection Induces Antibodies CrossReacting With Human Gastric Mucosa R. Negrini, L. Lisato, I. Zanella, L. Cavazzini, S. Gullini, V. Villanacci, C. Poiesi, A. Albertini, and S. Ghielml

\section{LIVER, PANCREAS, AND BILIARY TRACT}

446 Activation of Mast Cells by Bile Acids R.G. Quist, H.-T. TON-Nu, J. Lillienau, A.F. HOFMAN'N, AND K.E. BARRETT

457 Cell Type-Dependent Effect of Phospholipid and Cholesterol on Bile Salt Cytotoxicity A.L.M. Velardi, A.K. Groen, R.P.J.O. ElferinK, R. VAN DER MEER, G. PALASCIANO, AND G.N.J. TYTGat

465 Pancreatic Lesions in the von Hippel-Lindau Syndrome H.P.H. NeumanN, E. Dinkel, H. Brambs, B. Wimmer, H. Friedburg, B. Volk, G. Sigmund, P. Riegler, K. HaAG, P. SCHOLLMEYER, AND O.D. WIESTLER

472 The Stomach in Liver Cirrhosis S. Vigneri, R. Termini, A. Piraino, A. Scialabba, G. Pisciotta, AND N. FONTANA

479 Bile Evacuation Induced by Hypothalamic Stimulation in Dogs N. Furukawa AND H. OKada

490 Comparative Evaluation of Chenodeoxycholic and Ursodeoxycholic Acids in Obese Patients G. Mazzella, F. Bazzoli, D. Festi, M. Ronchi, R. Aldini, A. Roda, B. Grigolo, P. Simoni, N. Villanova, and E. Roda
497 Comparison of 1 or $3 \mathrm{MU}$ of Interferon Alfa-2b and Placebo in Patients With Chronic Non-A, Non-B Hepatitis X. Causse, H. Godinot, M. Chevallier, P. Chossegros, F. Zoulim, D. OUzan, J.-P. Heyraud, T. Fontanges, J. AlBRECH'T, C. MESCHIEvitZ, AND C. TREPO

503 Role of Cholecystokinin in the Regulation of Gastric Emptying and Pancreatic Enzyme Secretion in Humans M. FrIED, U. ERLACHER, W. SCHWIZER, C. LÖCHNER, J. KOERFER, C. BEglinger, J.B. JANSEN, C.B. LAMERS, F. HARDER, A. Bischof-Delaloye, G.A. STALDER, AND L. Rovati

512 Intraductal Mucin-Hypersecreting Neoplasms of the Pancreas F. Rickaert, M. Cremer, J. Devière, L. Tavares, J.P. LAMBILLIOTTE, S. SCHRÖDER, D. WURBS, AND G. KLÖPPEL

\section{CASE REPORTS}

520 Intestinal and Hepatic Apolipoprotein B Gene Expression in Abetalipoproteinemia

D.D. BlaCK, R.V. HAY, P.L. ROHWER-NUTTER, H. ElLINAS, J.K. STEPHENS, H. SHERMAN, B.-B. TENG, P.F. Whitington, AND N.O. DAVIDSON

529 Rhabdomyolysis and Cutaneous Necrosis Following Intravenous Vasopressin Infusion D. Moreno-Sánchez, B. Casis, A. Martín, P. Ortiz G. Castellano, M.T. MuÑoz, F. Vanaclocha, AND J.A. SOLÍS-HERruZO

533 Idiopathic Myointimal Hyperplasia of Mesenteric Veins R.M. GENTA AND R.C. HAGGITT

\section{BRIEF REPORTS}

540 Metabolism of Trinitrobenzene Sulfonic Acid by the Rat Colon Produces Reactive Oxygen Species M.B. Grisham, C. Volkmer, P. Tso, and T. Yamada

\section{SPECIAL REPORTS AND REVIEWS}

548 Reports From the NIH DDDN F.A. Hamilton and J.H. HoOfNagle

\section{SELECTED SUMMARIES}

550 Antibiotic Prophylaxis for Prevention of Spontaneous Bacterial Peritonitis?

552 Nitroglycerin in the Treatment of Portal Hypertension

553 Endoscopic Management of Gastric Outlet Obstruction 554 At Long Last-The Histamine $\mathrm{H}_{2}$-Receptor Gene Is Cloned 555 NSAID-Induced Gastroduodenal Injury: What's the Score?

558 BOOK REVIEWS

\section{TRAINING AND EDUCATION IN GASTROENTEROLOGY}

560 List of Available Training Programs

\section{CORRESPONDENCE}

589 Ethanol Stimulates Pepsinogen Release From Isolated Guinea Pig Chief Cells

590 Hemodynamic Events in a Prospective Randomized Trial of Propranolol Versus Placebo in the Prevention of a First Variceal Hemorrhage 
592 The Possible Role of Phospholipase in Gallstone Pathogenesis

593 Host Response to Mycobacterial Infection in the Alcoholic Rat

594 Tumor Necrosis Factor $\alpha$ in the Pathophysiology of Necrotizing Enterocolitis
594 Fasting and Postprandial Residual Gallbladder Volumes

595 CORRECTION

NO. 3, SEPTEMBER 1991

597 This Month in GASTROENTEROLOGY

\section{ALIMENTARY TRACT}

599 The Cephalic and Gastric Phases of Gastric Secretion During $\mathrm{H}_{2}$-Antagonist Treatment

H.S. MERKI, C.H. WILdER-SMITH, R.P. WALT, AND F. Halter

607 Effect of Intrathoracic Pressure on Plasma Arginine Vasopressin Levels

J.A. Solis-Herruzo, D. Moreno, A. Gonzalez, L. Larrodera,

G. Castellano, J. Gutierrez, and A. Gozalo

618 Expression of Sucrase-Isomaltase and Dipeptidylpeptidase IV in Human Small Intestine and Colon J.P. Gorvel, A. Ferrero, L. Chambraud, A. Rigal, J. Bonicel. AND S. MAROUX

626 Intestinal Obstruction During Shigellosis: Incidence, Clinical Features, Risk Factors, and Outcome M.L. BENNISH, A.K. AZAD, AND D. YOUSEFZADEH

635 Sulindac Causes Regression of Rectal Polyps in Familial Adenomatous Polyposis

D. Labayle, D. Fischer, P. Vielh, F. Drouhin, A. Pariente,

C. Bories, O. Duhamil, M. Trousset, and P. Attall

640 Radioautographic Localization of Epidermal Growth Factor Receptors in Human Fetal Gut

D. MÉNARD AND P. POTHIER

650 Observations on a Proposed Measure of Genotoxicity in Rat Gastric Mucosa

S. HOLT, Z. ZHAO-HUA, AND R.E. POWERS

657 Hypertrophic Smooth Muscle in the Partially Obstructed Opossum Esophagus

J.L. Conklin, C. Du, K. Schulze-Delrieu, and S. Shirazi

664 Trichinella spiralis Infection Alters Small Bowel Motor Activity in the Fed State

V.E. COWLES AND S.K. SARNA

670 Immunohistochemical Characterization, Distribution, and Ultrastructure of Lymphocytes Bearing T-Cell Receptor $\gamma / \delta$ in Inflammatory Bowel Disease

K. Fukushima, T. Masuda, H. Ohtani, I. Sasaki, Y. Funayama, S. Matsuno, and H. Nagura

679 Quality of Life After Proctocolectomy L.W. Köhler, J.H. Pemberton, A.R. Zinsmeister, AND K.A. KELLY

685 Acute Abdomen as the First Presentation of Pseudomembranous Colitis

G. TRIADAFILOPOUlos AND A.E. HaLlstonE
692 Isolation, Characterization, and Attachment of Rabbit Distal Colon Epithelial Cells

R.V. BENYA, L.N. SCHMIDT, J. SAHI, T.J. LAYDEN, AND M.C. RAO

703 Mechanism for the Gastrokinetic Action of Domperidone T. Takahashi, S. Kurosawa, J.W. Wiley, and C. OWyang

711 Cancer Incidence Following Subtotal Gastrectomy G.N. Stemmermann, A.M.Y. NOMURA, and P.-H. Chyou

716 Rat Enterocyte Injury by Oxygen-Dependent Processes S.S. BAKER AND C.L. CAMPBELL

721 Fecal Carriage of Streptococcus bovis and Colorectal Adenomas

R. Dubrow, S. Edberg, E. Wikfors, D. Callan, F. Troncale, R. VENDER, M. BRAND, AND R. YAPP

726 Antitumor Effect of Synthetic Derivatives of Lipid A in an Experimental Model of Colon Cancer in the Rat J.-F. Jeaninin, N. Onier, P. Lagadec, N. von Jeney, P. Stütz, AND E. LIEHI.

734 Neural and Hormonal Mechanisms Mediate the Enterogastric Reflex: A Study in Intestinal Transplants in Rats

S.L. OrlofF, N.W. BunnetT, H. WONG, J.H. WALSH, AND H.T. DEBAS

743 Classic and Vigorous Achalasia: A Comparison of Manometric, Radiographic, and Clinical Findings S.P. GoldenberG, M. Burrell, G.G. Fette, C. Vos, AND M. TRAUBE

749 Apolipoprotein Synthesis in Normal and Abetalipoproteinemic Intestinal Mucosa R.M. Glickman, J.N. Glickman, A. Magun, and M. BRin

756 Nonsalicylate Nonsteroidal Antiinflammatory Drugs Augment Prestimulated Acid Secretion in Rabbit Parietal Cells

R.A. LEVINE, J. NANDI, AND R.L. KING

\section{LIVER, PANCREAS, AND BILIARY TRACT}

766 Detection and Partial Sequencing of Hepatitis C Virus RNA in the Liver

K. Hosoda, O. Yokosuka, M. Omata, N. Kato, and M. Ohto

772 The Effects of Benzodiazepine-Receptor Antagonists and Partial Inverse Agonists on Acute Hepatic Encephalopathy in the Rat D.K. BOSMAN, C.A.C.G. vaN DEN BUIJ, J.G. DE HAAN, M.A.W. MAAS, AND R.A.F.M. CHAMULEAU 
782 Elevation of Serum Interleukin-6 Concentration Precedes Acute-Phase Response and Reflects Severity in Acute Pancreatitis

H.-G. Leser, V. Gross, C. Scheibendogen, A. Heinisch, R. Salm, M. LAUSEN, K. RÜCKAUER, R. ANDREESEN, E.H. FARTHMANN, AND J. SCHÖLMERICH

786 Acalculous Biliary Pain: Cholecystectomy Alleviates Symptoms in Patients With Abnormal Cholescintigraphy L. YAP, A.G. WYCHERLEY, A.D. MORPHETT, AND J. TOOULI

794 Noninvasive Measurement of Liver Regeneration With Positron Emission Tomography and $\left[2 \cdot{ }^{11} \mathrm{C}\right]$ Thymidine T. VANDER Borght, L. LAMBotTe, S. Pauwels, D. Labar, C. BECKERS, AND C. DIVE

800 The Effects of Chronic Endoscopic Variceal Sclerotherapy on Portal Pressure in Cirrhotics J. KORULA AND P. RALLS

806 Chronic Dietary Iron Overload in Rats Results in Impaired Calcium Sequestration by Hepatic Mitochondria and Microsomes

R.S. BRITTON, R. O'NEILL, B.R. BACON

812 Inhibition of Prostaglandin Synthesis Fails to Prevent Gallbladder Mucin Hypersecretion in the Cholesterol-Fed Prairie Dog D.P. O'Leary, W.W. LAMorTe, T.E. SCOTT, M.L. BOOKER, AND J. STEVENSON

821 Microanalysis of Bile Acid Composition in Intrahepatic Calculi and Its Etiological Significance J. Shoda, N. Tanaka, Y. Matsuzaki, A. Honda, T. Osuga, S. Shigematsu, and H. Miyazakl

\section{CASE REPORTS}

831 Clonorchis-Associated Cholangiocarcinoma: A Report of Two Cases With Unusual Manifestations F.V. Ona AND J.N.T. Dytoc,

\section{BRIEF REPORTS}

840 Interferon-Induced Chronic Active Hepatitis? M.O. Silva, K.R. REDDY, L.J. JEFFERS, M. HILL, AND E.R. SCHIFF

\section{SPECIAL REPORTS AND REVIEWS}

843 A Reappraisal of the Magnitude and Implications of the Intestinal Unstirred Layer A. STROCCHI AND M.D. LEVITT

\section{CLINICAL CHALLENGES}

848 Hypoproteinemia, Anemia, and Failure to Thrive in an Infant

J.E. BINES AND E.J. ISRAEL

\section{EDITORIALS}

857 Lessons From Experimental Cholelithiasis: Gallbladder and Mucosa, Nonsteroidal Antiinflammatory Drugs, and Gallstones S.P. LEE

\section{SELECTED SUMMARIES}

861 One More Reason for Weight Loss in Patients With AIDS

862 Hepatitis B and Human Immunodeficiency Virus: Double Trouble

863 Acute and Chronic Giant Cell Hepatitis: A Paramyxovirus Infection?

864 Peliosis Hepatis: Old Disease, New Cause

866 A Biopsychosocial Model for Functional Dyspepsia

869 BOOK REVIEWS

\section{CORRESPONDENCE}

871 Vegetable Peroxidase Is Denatured by Gastric Acid

871 Estimation of Risk of Transmission of Non-A, Non-B Hepatitis by Needlestick Injury

872 Free Radical Scavengers and Inflammatory Bowel Disease

872 Role of Parenteral Nutrition in Crohn's Colitis

874 Treatment of Intestinal Cryptosporidiosis With Zidovudine and SMS 201-995, a Somatostatin Analog

874 Somatostatin and Acute Variceal Hemorrhage

875 Prevalence of Columnar-Lined (Barrett's) Esophagus

876 Asthmatics' Gastroesophageal Reflux With or Without Bronchodilator Therapy

878 NOTICES

NO. 4, OCTOBER 1991

879 This Month in GASTROENTEROLOGY

\section{ALIMENTARY TRACT}

881 Comparison of Enteral Nutrition and Drug Treatment in Active Crohn's Disease

H. LOCHS, H.J. STEINHARDT, B. Klaus-WENTZ, M. ZeitZ, H. Vogelsang, H. SOMmer, W.E. Fleig, P. BAuer, J. SCHIRRMEISTER, AND H. MALCHOW
889 The Effect of Histamine $\mathrm{H}_{2}$-Receptor Blockade on Bismuth Absorption From Three Ulcer-Healing Compounds C.U. Nwokolo, E.J. PrewetT, A.M. SAWYERR, M. HudSON, AND R.E. POUNDER

895 Electrolyte Transport in Piglets Infected With Transmissible Gastroenteritis Virus F.R. HOMAIDAN, A. TORRES, M. DONOWITZ, AND G.W.G. SHARP

902 Comparative Evaluation of Acid- and Bile-Induced Damage to Pedicled Jejunal or Colonic Segments in the Rat G.B. Ratto, P. Romano, And D. Zaccheo 
910 Mechanism of Inhibitory Action of Prostaglandins on the Growth of Human Gastric Carcinoma Cell Line KATO III A. Nakamura, T. Yamatani, T. Fuitta, and T. Chiba

919 Comparative Evaluation of Carcinoembryonic Antigen, Secretory Component, and Mucins in Index and Metachronous Adenomas of the Colorectum G. Griffioen, F.T. Bosman, H.W. Verspaget, K.F.M. Sier, I. BIEMOND, AND C.B.H.W. LAMERS

927 Epidemiology of Colonic Symptoms and the Irritable Bowel Syndrome N.J. TAlley, A.R. Zinsmeister, C. VAN Dyke, AND L.J. MELTON III

935 Action of Beer and Its Ingredients on Gastric Acid Secretion and Release of Gastrin in Humans M.V. Singer, S. TEYSSEN, AND V.E. EYSSELEIN

943 Omeprazole Treatment Does Not Affect the Metabolism of Caffeine

T. Andersson, R. Bergstrand, C. Cederberg, S. Eriksson, P.-O. LAGERSTRÖM, AND I. SKÅNBERG

948 Tolerance During 5 Months of Dosing With Ranitidine, 150 mg Nightly: A Placebo-Controlled, Double-Blind Study C.U. Nwokolo, E.J. Prewett, A.M. Sawyerr, M. Hudson, S. LIM, AND R.E. POUNDER

954 Role of Capsaicin-Sensitive Afferent Neurons in Alkaline Secretory Response to Luminal Acid in the Rat Duodenum K. TakeuChi, J. Matsumoto, K. Ueshima, and S. OKabE.

962 Reverse-Perfused Sleeve: An Improved Device for Measurement of Sphincteric Function of the Crural Diaphragm

B. SIVRI AND R.K. MITTAL

970 Opioids Inhibit Neuromuscular Transmission in Circular Muscle of Human and Baboon Jejunum

A.J. BAUER, M.G. SARR, AND J.H. SZURSZEWSKI

977 Effect of Age on Gastric Acid Secretion and Serum Gastrin Concentrations in Healthy Men and Women

M. GoldSChmiEDT, C.C. BARnetT, B.E. Schwarz, W.E. Karnes, J.S. REDFERN, AND M. FELDMAN

991 Enterogastric Reflux After Various Types of Antiulcer Gastric Surgery: Quantitation by ${ }^{99 m}$ Tc-HIDA Scintigraphy E. Xynos, J.S. Vassilakis, A. Fountos, G. Pechlivanides, AND N. KaRKAVITSAS

999 The Origin of Symptoms on the Brain-Gut Axis in Functional Dyspepsia

F. MEarin, M. Cucala, F. AzPiroz, and J.-R. Malagelada

1007 Electroencephalogram Patterns During Sleep Reflux in Infants

J.M. SONDHEIMER AND E. HODDES

1012 In Vivo Evidence of Altered Chloride but Not Potassium Secretion in Cystic Fibrosis Rectal Mucosa

J.L. Goldstein, A.B. Shapiro, M.C. Rao, And T.J. LAyden

1020 Increased Activation of Isolated Intestinal Lamina Propria Mononuclear Cells in Inflammatory Bowel Disease S. Schreiber, R.P. MacDermott, A. RaEdler, R. Pinnau, M.J. BERTOVICH, AND G.S. NASH

1031 Effects of Diazepam and Ro 15-1788 on Duodenal Bicarbonate Secretion in the Rat B. SÄFSTEN, G. JEDSTEDT, AND G. FlEMSTRÖM
1039 Reversal of Protein-Bound Vitamin $B_{12}$ Malabsorption With Antibiotics in Atrophic Gastritis

P.M. SUTER, B.B. GOLNER, B.R. GOLDIN, F.D. MORROW, AND R.M. RUSSELL

1046 Short-Chain Glucose Polymer and Anthracene-9-carboxylic Acid Inhibit Water and Electrolyte Secretion Induced by Dibutyryl Cyclic AMP in the Small Intestine

G.H. Rabbant, R.-B. Lu, K. HoRvath, and E. Lebenthal

\section{LIVER, PANCREAS, AND BILIARY TRACT}

1054 Light and Electron Microscopy of Neuropeptide YContaining Nerves in Human Liver, Gallbladder, and Pancreas

W.-G. DinG, M. Fuimiura, A. Mori, I. TOOYAma, AND H. KIMURA

1060 Ornipressin in the Treatment of Functional Renal Failure in Decompensated Liver Cirrhosis

K. Lenz, H. Hörtnagl, W. Druml, H. Reither, R. Schmid,

B. SChNeEweiss, A. LaGgner, G. Grimm, and A.L. Gerbes

1068 Complications of Endoscopic Sphincterotomy S. Sherman, T.A. Ruffolo, R.H. HAWES, and G.A. LEHMAN

1076 Defective Fc Receptor-Mediated Clearance in Patients With Primary Biliary Cirrhosis K. NiLSSON EKDAHL, L. LÖÖF, A. NYBERG, U.R. NILSSON, AND B. NILSSON

1083 Azathioprine Treatment Increases Hepatocyte Turnover N. ARBER, G. ZAIICEK, J. NORDENBERG, AND Y. SidI

1087 Prophylactic Sclerotherapy in High-Risk Cirrhotics Selected by Endoscopic Criteria R. de Franchis, M. Primignani, P.G. Arcidiacono, P.M. Rizzi, P. Vitagliano, M.C. Vazzoler, R. Arcidiacono, A. Rossi, A. Zambelli, F. Cosintino, G. Caletti, S. Brunati,

G. Battaglia, and G. Gerunda

$1094 \mathrm{An} \mathrm{Na}^{+}$-Dependent and an $\mathrm{Na}^{+}$-Independent System for Glutamine Transport in Rat Liver Basolateral Membrane Vesicles

H.M. SAID, D. HOLLANDER, AND S. KHORCHID

1102 Glucocorticoids Stimulate Ornithine Decarboxylase Gene Expression in Pancreatic AR42J Cells

S. ROSEWICZ AND C.D. LOGSDON

1109 Aspirin Does Not Inhibit Cholesterol Cholelithiasis in Two Established Animal Models B.I. COHEN, E.H. MOSBACH, N. AYyad, M. YoshiI, AND C.K. MCSHERRY

\section{BRIEF REPORTS}

1117 Hepatitis C Virus Antibodies in Acute Icteric and Chronic Non-A, Non-B Hepatitis J.G. MCHutchison, G. KuO, M. HoughtoN, Q.-L. ChOO, AND A.G. REDEKER

\section{CLINICAL CHALLENGES}

1120 Fecal Incontinence in a 39-Year-Old Man R.J. MAY

\section{EDITORIALS}

1127 Enteral Feeding Versus Drug Therapy in Crohn's Disease: A Continuing Story J.W. SINGLETON 


\section{SELECTED SUMMARIES}

1129 Treatment of Severe Postgastrectomy Dumping With a Long-Acting Somatostatin Analog: Is Effective Management Finally Available?

1130 Sulfasalazine vs. Steroids in Crohn's Disease: David vs. Goliath?

1131 Recurrent Hepatitis B in Liver Transplant Recipients-No Easy Answers

1133 Sporadic vs. Posttransfusion Hepatitis C: Why the Differences?

1134 Bidirectional Communication Between Mast Cells and Nerves Controls Intestinal Secretion
1137 BOOK REVIEWS

\section{CORRESPONDENCE}

1139 Concentration in Pancreatic Juice of Lithostathine

1140 Pathogenesis and Treatment of Rotavirus Diarrhea

1141 Prevalence of Spontaneous Hepatofugal Portal Flow in Liver Cirrhosis

1142 Enteric Neuronal Autoantibodies in Pseudoobstruction With Small-Cell Lung Carcinoma

1144 Hyperplastic Polyps and Risk of Adenomas

1146 NOTICES

NO. 5, NOVEMBER 1991

1147 This Month in GASTROENTEROLOGY

\section{ALIMENTARY TRACT}

1149 A Critical Analysis, With Appropriate Controls, of Gastric Acid and Pepsin Secretion in Clinical Esophagitis B.I. HIRSCHOWITZ

1159 Primary B-Cell Gastric Lymphoma: A Clinicopathological Study of 145 Patients

S.B. COGliatTI, U. SCHMid, U. SCHUMACHER, F. ECKERT, M.-L. HANSMANN, J. HedDERICH, H. TAKahashi, AND K. LenNeRT

1171 Value of Transrectal Ultrasonography in Crohn's Disease M.J. Van Outryve, P.A. Pelckmans, P.P. Michielsen, AND Y.M. VAN MAERCKE:

$1178 \gamma$-Aminobutyric Acid Localization and Function as Modulator of Cholinergic Neurotransmission in Rat Antral Mucosal/Submucosal Fragments R.F. HARTY, M.G. Boharski, G.S. Bochna, T.A. CARR, P.E. EAGAN, M. RINGS, D.C. LaSSITER, M.P. POUR, D.F. SCHAFER, AND R.S. MARKIN

1187 Histological Maturity of Healed Duodenal Ulcers and Ulcer Recurrence After Treatment With Colloidal Bismuth Subcitrate or Cimetidine S. PAN, C.-H. LIAO, G.-S. LIEN, AND S.-H. CHEN

1192 Portal Colopathy: Prospective Study of Colonoscopy in Patients With Portal Hypertension

R.A. KozAREK, V.A. Botoman, J.E. BREDFELDT, J.M. ROACH, D.J. PATTERSON, AND T.J. BALL

1198 Distribution of Aneuploid Cell Populations in Ulcerative Colitis With Dysplasia or Cancer D.S. LEVINE, P.S. Rabinovitch, R.C. HagGitT, P.L. BlounT, P.J. DEAN, C.E. RuBIN, AND B.J. REID

1211 Calcitonin Gene-Related Peptide and Substance P Decrease in the Rabbit Colon During Colitis V.E. Eysselein, M. Reinshagen, F. Cominelli, C. Sternini, W. Davis, A. Patel, C.C. Nast, D. Bernstein, K. Anderson, H. KHAN, AND W.J. SNAPE, JR.

1220 Mechanisms of Acid Injury to Rabbit Esophageal Epithelium

N.A. TOBEY AND R.C. ORLANDO
1229 Prostaglandins and the Colonic Epithelium R.A. Goodlad, N. Mandir, S. Levin, J.L. Allen, AND N.A. WRIGHT

1235 Morphometry and Cell Proliferation in Endoscopic Biopsies: Evaluation of a Technique R.A. GoOdlad, S. Levi, C.Y. LeE, N. Mandir, H. Hodgson, AND N.A. WRIGHT

1242 The Role of Vasopressin in the Pathogenesis of EthanolInduced Gastric Hemorrhagic Erosions in Rats F. LÁSZLó, G. KaRÁCSONY, E. SZABÓ, J. LÁNG, L. BALÁSPIRI, AND F.A. LÁSZLÓ

1249 Central and Peripheral Control of Postprandial Pyloric Motility by Endogenous Opiates and Cholecystokinin in Dogs

Y. LOPEZ, J. FIORAMONTI, AND L. BUENO

1256 Peptidergic Innervation of the Human Esophageal Smooth Muscle

C. Singaram, A. Sengupta, D.J. Sugarbaker, and R.K. Goyal

1264 Changes in the Structure and Regeneration Mode of the Rat Small Intestinal Mucosa Following Benzalkonium Chloride Treatment G.E. HOLLE

1274 Different Fibers Have Different Regional Effects on Luminal Contents of Rat Colon A. MCInTYRE, G.P. Young, T. TARANTO, P.R. Gibson, AND P.B. WARD

1282 Inversion of the Slow-Wave Frequency Gradient in Symptomatic Patients With Roux-en-Y Anastomoses G. Vantrappen, G. Coremans, J. Janssens, A. Mantides, AND F. VANDEN BORRE

1289 Colonic Motility and Transit in Health and Ulcerative Colitis

S.N. Reddy, G. Bazzocchi, S. Chan, K. AKashi,

J. Villanueva-Meyer, G. YanNI, I. Mena, And W.J. Snape, JR.

1298 Effect of Eating on Colonic Motility and Transit in Patients With Functional Diarrhea

G. BazzocChi, J. Ellis, J. Villanueva-Meyer, S.N. Reddy, I. MENA, AND W.J. SNAPE, JR. 
1307 Quality of Life of Patients With Ulcerative Colitis Preoperatively and Postoperatively R.S. MCLEOD, D.N. ChuRCHILl, A.M. LOCK, S. VANDERBURGH, AND Z. COHEN

1314 Perendoscopic Manometry of the Distal Ileum and Ileocecal Junction in Humans

E. Corazziari, F. Barberani, M. Tosoni, S. Boschetto, AND A. TORSOLI

1320 Delayed Gastrointestinal Transit Times in Anorexia Nervosa and Bulimia Nervosa

N. Kamal, T. Chami, A. Andersen, F.A. Rosell, M.M. SCHUSTER, AND W.E. WHITEHEAD

\section{LIVER, PANCREAS, AND BILIARY TRACT}

1325 Ultrasonic Tissue Characterization of Chronic Liver Disease Using Cepstral Analysis K. SuzukI, N. Hayashl, Y. Sasaki, M. Kono, Y. Imal, H. FUSAMOTO, AND T. KAMADA

1332 Treatment of Primary Biliary Cirrhosis With Low-Dose Weekly Methotrexate

M.M. KAPLAN AND T.A. KNOX

1339 Effect of Phospholipase $C$ on Cholesterol Solubilization in Model Bile

N.R. PATTINSON AND K.E. WILLIS

1345 Effectiveness of a Purified Human Hemoglobin as a Blood Substitute in the Perfused Rat Liver

H.F. Starnes, Jr., A. Tewari, K. Flokas, J.C. Kosek, D. BROWN, A.L. VAN-KESSEL, AND C.F. MONDON

1354 Abnormal Sympathetic and Renal Response to Sodium Restriction in Compensated Cirrhosis M.-A. Simón, J. Díez, AND J. PRIETo

1361 Lipase/Amylase Ratio V.V. Gumaste, P.B. Dave, D. Weissman, and J. Messer

1367 HLA DRw8 and Complement C4 Deficiency as Risk Factors in Primary Biliary Cirrhosis

M.P. Manns, A. Brfmm, P.M. Schneidfr, A. Notghi, G. Gerken, M. Prager-Eberle, B. Stradmann-Bellinghausen, K.-H. MEYER ZUM BÜSCHENFELDE, AND C. RITTNER

1374 Risk Factors for Septicemia Following Endoscopic Biliary Stenting

S. MotTe, J. Deviere, J.-M. Dumonceau, E. SerruYs,

J.-P. THYS, AND M. CREMER

1382 A Shift in Balance Between Profibrinolytic and Antifibrinolytic Factors Causes Enhanced Fibrinolysis in Cirrhosis

F.W.G. LeEbeEk, C. KLuft, E.A.R. KNOT, M.P.M. DE MAAT, AND J.H.P. WILSON

1391 Lithotripsy of Gallstones by Means of a Quality-Switched Giant-Pulse Neodymium:Yttrium-Aluminum-Garnet Laser J. HOChBERGER, E. GRUBer, P. WirTZ, U. DÜRR, A. KolB, U. ZANGER, E.G. HAHN, AND C. ElL

1399 Portal and Biliary Phases of Enterohepatic Circulation of Corrinoids in Humans

S. El Kholty, J.-L. GueAnt, L. Bressler, M. Djalali,

P. BoISSEL, P. GERARD, AND J.-P. NiCOLAS

1409 Significance of Computed Tomography for Shock-Wave Therapy of Radiolucent Gallbladder Stones

C. ELL, H.T. SCHNEIDER, J. BENNINGER, S. THEOBALDY, N. FrIEDEL, W. RÖDL, P. WIRTZ, AND E.G. HAHN

\section{CASE REPORTS}

1417 Postinfantile Giant Cell Hepatitis in Association With Hypereosinophilia

A. KUMAR AND G.Y. MINUK

1420 Idiopathic Neonatal Iron-Storage Disease J.A. BARNARD III AND E. MANCI

\section{BRIEF REPORTS}

1428 Cholecystokinin-Mediated Ileal Electrolyte Transport in the Guinea Pig

J.F. KACHUR, S.-X. WANG, G.W. GULLIKSON, AND T.S. GAGINELLA

\section{CLINICAL CHALLENGES}

1432 Recurrent Gastrointestinal Bleeding Associated With Myelofibrosis and Diffuse Intestinal Telangiectasias S.D. FrEEDMAN, R.E. DREWS, D.J. GLOTZER, D. KIM, H. GARDNER, AND S.J. GALLI

\section{EDITORLALS}

1440 Methotrexate Therapy of Primary Biliary Cirrhosis: Promising but Worrisome

J.H. HOOFNAGLE AND N.V. BERGASA

\section{SELECTED SUMMARIES}

1443 Pregnancy in Liver Transplant Patients-And Vice Versa

1444 The p53 Gene and Hepatocellular Carcinoma

1445 Transforming Growth Factors in Human Chronic Hepatitis and Cirrhosis: Correlations With Fibrogenesis and Hepatic Regeneration

1446 Somatostatin Therapy for AIDS Diarrhea: Muddy Waters

$1448 \mathrm{H}_{2}$ Antagonists by Continuous Infusion: IV or IG?

\section{BOOK REVIEWS}

\section{CORRESPONDENCE}

1452 Functional Bowel Disease: The Role of Fructose and Sorbitol

1453 Role of Fructose-Sorbitol Malabsorption in the Irritable Bowel Syndrome

1454 Fructose Malabsorption and the Irritable Bowel Syndrome

1454 Helicobacter pylori Infection and Inflammation of the Gastric Corpus

1455 Postparacentesis Plasma Expansion Prevents Asymptomatic Laboratory Abnormalities, but Does It Have Any Impact on Morbidity or Mortality?

1457 Cancer Risk in Left-Sided Colitis

1458 Stress Ulcer Prophylaxis

1459 The Use of 6-Mercaptopurine in Adolescents With Crohn's Disease

1460 CORRECTIONS

1461 NOTICES 
NO. 6, DECEMBER 1991

1463 This Month in GASTROENTEROLOGY

\section{AMERICAN GASTROENTEROLOGICAL ASSOCIATION}

1465 Presidential Address D.H. ALPERS

1468 Presentation of the Julius Friedenwald Medal to Cyrus E. Rubin, M.D.

W.M. WEINSTEIN

\section{ALIMENTARY TRACT}

1471 Galanin Inhibition of Vasoactive Intestinal Polypeptide Release and Circular Muscle Motility in the Isolated Perfused Canine Ileum

J.-A.E.T. Fox-THRELKELD, T.J. MCDONALD, S. CiPRIS, Z. WOSKOWSKA, AND E.E. DANIEI

1477 The Minor Components of the Rat Asialoglycoprotein Receptor Are Apically Located in Neonatal Enterocytes C. Hu, E.Y. LEe, J.E. HewITT, J.U. BAENZIGER, J.-Z. Mu, K. DeSChryVER-KeCSKEMETI, AND D.H. Alpers

1488 Gastrointestinal Motor Effects of Erythromycin in Humans S.K. SARNA, K.H. SOERGEL, T.R. KOCH, J.E. STONE, C.M. WOOD, R.P. Ryan, R.C. ARndorfer, J.H. Cavanaugh, H.N. Nellans, AND M.B. LEE

1497 Colonic Fermentation to Short-Chain Fatty Acids Is Decreased in Antibiotic-Associated Diarrhea M.R. Clausen, H. BonnÉn, M. TVEDE, ANd P.B. Mortensen

1505 Differential Effect on Neuropeptide Release of Different Concentrations of Hydrogen Ions on Afferent and Intrinsic Neurons of the Rat Stomach

P. Geppetti, M. Tramontana, S. Evangelista, D. Renzi,

C.A. Maggi, B.M. Fusco, and E. Del Bianco

1512 High Incidence of Esophageal Motor Disorders in Consecutive Patients With Globus Sensation

G. Moser, G.V. Vacariu-Granser, C. SChNeider, T.-A. Abatzi, P. Pokieser, G. STACHER-JANOtTA, G. GaupmanN, U. Weber,

T. WENZEL, M. RODEN, AND G. STACHER

1522 Imbalance of Plasminogen Activators and Their Inhibitors in Human Colorectal Neoplasia

C.F.M. Sier, H.W. Verspaget, G. Griffioen, J.H. VerheijeN, P.H.A. QuAX, G. DoOIJEWAaRd, P.A.F. DE BRUIN, AND C.B.H.W. LAMERS

1529 Activation and Signaling Status of Human Lamina Propria T Lymphocytes

L. QiaO, G. SChÜrmanN, M. Betzler, and S.C. MEUER

1537 Colonic Motor Response to a Meal in Acute Colitis A.K. SETHI AND S.K. SARNA

1547 Antral Gastrin Cell Hyperfunction in Children B. AnNibale, M. Bonamico, G. Rindi, L. Villani, E. Ferrante, A. Vania, E. Solcia, and G. Delle Fave

1552 Regulation of Rat Antral Gastrin and Somatostatin Gene Expression During Starvation and After Refeeding V. WU, K. SUMII, A. TARI, M. SUMII, AND J.H. WALSH

1559 Radial and Longitudinal Asymmetry of Human Pharyngeal Pressures During Swallowing

V.W. SEars, JR., J.A. CASTEll, and D.O. Castell
1564 Cisapride in Children With Chronic Intestinal Pseudoobstruction

C. Di Lorenzo, S.N. Reddy, J. Villanueva-Meyer, I. MEnA, S. MARTIN, AND P.E. HYMAN

1571 Colonic Motility in Innervated and Extrinsically Denervated Loops in Dogs

C. Shibata, I. Sasaki, S. Matsuno, A. Mizumoto, and Z. Itoh

1579 Dual Effect of Trimebutine on Contractility of the Guinea Pig Ileum via the Opioid Receptors

K. Taniyama, I. Sano, S. Nakayama, S. Matsuyama, K. TAKEDA, C. YoshIHARA, AND C. TANAKA

1588 Flow-Cytometric DNA Content Analysis of Esophageal Squamous Cell Carcinomas M. Robaszkiewicz, B.J. Reid, A. Volant, J.M. Cauvin, P.S. RABINOVITCH, AND H. GOUEROU

1594 Loss of Interleukin-2-Producing Intestinal CD4 + T Cells in Inflammatory Bowel Disease

K. Kusugami, T. MatsuUra, G.A. West, K.R. Youngman,

D. RACHMILEWITZ, AND C. FIOCCHI

1606 Sensorial and Intestinointestinal Reflex Pathways in the Human Jejunum J.-M. ROUILLON, F. AzPIROZ, AND J.-R. MALAGELADA

1613 Modification of the Effects of Blood on Amino Acid Metabolism by Intravenous Isoleucine N.E.P. DEuTZ, P.L.M. REIJVEN, M.C.F. BOST, C.L.H. van BERLO, AND P.B. SOETERS

1621 Enhanced Perception of Physiological Intestinal Motility in the Irritable Bowel Syndrome J.E. KELLOW, G.M. ECKERSLEY, AND M.P. JONES

\section{LIVER, PANCREAS, AND BILIARY TRACT}

1628 Gas in Gallstones: Quantitative Determinations and Possible Effects on Fragmentation by Shock Waves N. VAKIL AND E.C. EVERBACH

1635 The Antiinflammatory Effect of Dopamine in Alcoholic Hemorrhagic Pancreatitis in Cats N.D. Karanila, A.L. Widdison, F.J. LutRIn, Y.-B. Chang, AND H.A. REBER

1642 A Prospective Controlled Study of the Risk of Bacteremia in Emergency Sclerotherapy of Esophageal Varices H. HO, M.J. ZUCKERMAN, AND C. WASSEM

1649 Patterns of Hepatitis Delta Virus Reinfection and Disease in Liver Transplantation A. Ottobrelli, A. Marzano, A. Smedile, S. Recchia, M. SAlizzoni, C. CORnu, M.E. LAMY, J.B. OtTE, B. de Hemptinne, A. Geubel, M. Grendele, M. Colledan, D. Galmarini, G. MarinucCi, C. Di Giacomo, S. Agnes, F. BONINO, AND M. RIZZETTO

1656 Spontaneous Bacterial Peritonitis in Patients With Hepatitis B-Related Cirrhosis and Hepatocellular Carcinoma

S.-S. WANG, Y.-T. TSAI, S.-D. LEE, H.-T. CHEN, C.-W. LU, F.-Y. LEE, J.-S. JENG, Y.-C. LIU, AND K.-J. LO

1663 Regional Orientation of Actin Filaments in the Pericanalicular Cytoplasm of Rat Hepatocytes M. ISHII, H. WASHIOKA, A. TONOSAKI, AND T. TOYOTA 
1673 Acute Infusions of Bile Salts Increase Biliary Excretion of Iron in Iron-Loaded Rats

P. Lévy, M. Dumont, P. Brissot, A. Letreut, A. Favier,

Y. DEUGNIER, AND S. ERLINGER

1680 Differential Inhibition of Individual Human Liver Cytochromes P-450 by Cimetidine

R.G. KNODELL, D.G. BROWNE, G.P. GWOZDZ, W.R. BRIAN, AND F.P. GUENGERICH

1692 Experimental Evaluation of an Endoscopic Balloon for Manometry of Esophageal Varices

P. GerTSCH, A.M. WheATley, R. MAibaCh, G.J. MADDERN, AND J.-N. VAUTHEY

1701 Occult Microlithiasis in 'Idiopathic' Acute Pancreatitis: Prevention of Relapses by Cholecystectomy or Ursodeoxycholic Acid Therapy

E. Ros, S. Navarro, C. Bru, A. Garcia-Pugés, AND R. VALDERRAMA

1710 Glucagon Hinders the Effects of Somatostatin on Portal Hypertension

M.P. Pizcueta, J.C. García-Pagán, M. Fernández,

R. Casamitjana, J. Bosch, ANd J. Rodés

1716 Intraacinar Profiles of Alcohol Dehydrogenase and Aldehyde Dehydrogenase Activities in Human Liver I.P. MALY AND D. SASSE

1724 Antibodies to Hepatitis C Virus in Low-Risk Blood Donors: Implications for Counseling Positive Donors H.H. Hsu, M. Gonzalez, S.K.H. Foung, S.M. Feinstone, AND H.B. GREENBERG

\section{CASE REPORTS}

1728 Successful Orthotopic Liver Transplantation in a Patient With Refractory Biliary Candidiasis

K.B. NOACK, D.R. OSMON, K.P. BATTS, M. WILHELM, R.A.F. KROM, AND K.D. LINDOR

1731 Acute Biliary-Vascular Fistula Following Needle Aspiration of the Liver M.S. VERHILLE AND S.J. MUÑOZ

1734 Severe Monochlorobenzene-Induced Liver Cell Necrosis G. Babany, J. Bernuau, A. Callleux, J.-F. Cadranel, C. Degott, S. Erlinger, and J.-P. Benhamou

1737 Severe Cholestatic Jaundice Associated With Piroxicam K.S. Hepps, G.M. MAliha, R. Estrada, and R.W. GoOngame

\section{EDITORIALS}

1741 Liver Transplantation: A Model for the Transmission of Hepatitis Delta Virus W.S. MASON AND J.M. TAYLOR

\section{SELECTED SUMMARIES}

1744 Laparoscopic Treatment of Duodenal Ulcer: A Plea for Clinical Trials

1745 Alcohol Abuse and Liver Disease: True, True, but Not Necessarily Related

1747 Sphincter of Oddi Manometry in Patients With Possible Sphincter of Oddi Dysfunction

1748 Palliation of Advanced Esophageal Cancer: A (Laser) Light at the End of the Tunnel

1750 Is Exercise Good for Gastrointestinal Function?

1752 BOOK REVIEWS

\section{CORRESPONDENCE}

1754 Extracorporeal Shock-Wave Lithotripsy for the Management of Bile Duct Stones: Is It Always a Safe Procedure?

1755 Microvillus Inclusion Disease

1756 Hyperplastic Polyps Do Not Predict Adenomatous Polyps

1757 A Role for NMR in Alcoholism?

1758 Whither Biliary Sludge-Do You Exist?

1759 Helicobacter pylori in Autoimmune Gastritis

1759 Propranolol for Prophylactic Treatment of a First Variceal Hemorrhage

1761 Intestinal Lymphangiectasia: Lack of Efficacy of Antiplasmin Therapy?

1761 CORRECTIONS

1762 NOTICES

1763 SPECIAL NOTICE

1768 AUTHOR INDEX TO VOLUME 101

1781 SUBJECT INDEX TO VOLUME 101 


\title{
Ornipressin in the Treatment of Functional Renal Failure in Decompensated Liver Cirrhosis
}

\author{
Effects on Renal Hemodynamics and Atrial \\ Natriuretic Factor
}

\author{
KURT LENZ, HEIDE HÖRTNAGL, WILFRED DRUML, \\ HARALD REITHER, RAINER SCHMID, BRUNO SCHNEEWEISS, \\ ANTON LAGGNER, GEORG GRIMM, and ALEXANDER L. GERBES \\ 1st Department of Internal Medicine, Institute of Biochemical Pharmacology; Department of \\ Psychiatry, University of Vienna, Vienna, Austria; and Department of Medicine II, Klinikum \\ Großhadern, University of Munich, Munich, Germany
}

In 11 patients with decompensated cirrhosis and deteriorating renal function, the effect of the vasoconstrictor substance 8-ornithin vasopressin (ornipressin; POR 8; Sandoz, Basel, Switzerland) on renal function, hemodynamic parameters, and humoral mediators was studied. Ornipressin was infused at a dose of $6 \mathrm{IU} / \mathrm{h}$ over a period of 4 hours. During ornipressin infusion an improvement of renal function was achieved as indicated by significant increases in inulin clearance $(+65 \%)$, paraaminohippuric acid clearance $(+49 \%)$, urine volume $(+45 \%)$, sodium excretion $(+259 \%)$, and fractional elimination of sodium $(+130 \%)$. The hyperdynamic circulation was reversed to a nearly normal circulatory state. The increase in systemic vascular resistance $(+60 \%)$ coincided with a decrease of a previously elevated renal vascular resistance $(-27 \%)$ and increase in renal blood flow $(+44 \%)$. The renal fraction of the cardiac output increased from $2.3 \%$ to 4.7\% $(P<0.05)$. A decline of the elevated plasma levels of noradrenaline $(2.08-1.13 \mathrm{ng} / \mathrm{mL} ; P<0.01)$ and renin activity $\left(27.6-14.2 \mathrm{ng} \cdot \mathrm{mL}^{-1} \cdot \mathrm{h}^{-1} ; P<\right.$ 0.01) was achieved. The plasma concentration of the atrial natriuretic factor increased in most of the patients, but slightly decreased in 3 patients. The decrease of renal vascular resistance and the increase of renal blood flow and of the renal fraction of cardiac output play a key role in the beneficial effect of ornipressin on renal failure. These changes develop by an increase in mean arterial pressure, the reduction of the sympathetic activity, and probably of an extenuation of the splanchnic vasodilation. A significant contribution of atrial natriuretic factor is less likely. The present findings implicate that treatment with ornipressin represents an alternative approach to the management of functional renal failure in advanced liver cirrhosis.

Tncreasing evidence indicates that the use of vasoconstrictor substances represents a promising approach in the treatment of renal failure in advanced liver cirrhosis (1). An improvement of renal function has been achieved by administration of either $\alpha$-sympathomimetic drugs (2-4) or the vasopressin analogues octapressin $(5,6)$ and more recently 8-ornithin vasopressin (ornipressin) $(7,8)$. A normalization of sodium and water excretion has also been achieved by central blood volume expansion with head-out water immersion in combination with a noradrenaline infusion $(9,10)$.

Using a vasoconstrictor compound in advanced hepatic failure, one is confronted with the phenomenon of a pronounced arterial vasodilation in the systemic circulation that is counteracted by a profound vasoconstriction in the renal vasculature $(11,12)$. The renal vasoconstriction is, at least partly, related to an increased sympathetic tone in the kidney, because the blockade of the lumbal part of the sympathetic nerves that innervate the kidney im-

Abbreviations used in this paper: ANF, atrial natriuretic factor; FENa, fractional elimination of sodium; PAH, paraaminohippuric acid.

(1) 1991 by the American Gastroenterological Association 0016-5085/91/\$3.00 
proved renal function in cirrhotic patients (13). The obvious paradox of using a vasoconstrictor compound in the treatment of renal dysfunction that coincides with a profound vasoconstriction of the renal vasculature needs further clarification. Peripheral arterial vasodilation, which appears to be most excessive in the splanchnic territories, has been postulated to play a key role in the development of the circulatory derangement and renal failure in advanced liver cirrhosis (12,14-17). An efficient treatment of this circulatory derangement therefore requires a vasoconstrictor substance with a preferential action in the splanchnic vascular bed. In this respect, vasopressin or its analogues with reduced antidiuretic activity might be of considerable advantage because vasopressin is a much more potent vasoconstrictor of iliac and mesenteric than of renal beds $(18,19)$. In decompensated cirrhosis, ornipressin has been shown to increase creatinine clearance, urine volume, and sodium excretion and to normalize the hyperdynamic circulation (7). However, its effect on renal hemodynamics is less clear. A variable improvement of renal perfusion in cirrhotic patients was achieved using octapressin $(5,6)$. Preliminary data also indicate an improvement of renal hemodynamics during ornipressin infusion (20).

To achieve a better insight into the mechanisms involved in the ameliorating effect of vasoconstrictor drugs on renal function in advanced liver disease we investigated the influence of ornipressin on various indices of renal function and renal hemodynamics in cirrhotic patients with functional renal failure. In addition, the influence of ornipressin on endogenous systems that have a considerable impact on renal function, namely the atrial natriuretic factor (ANF) as well as the renin-angiotensin and sympathetic nervous systems, was analyzed.

\section{Patients and Methods}

\section{Patients}

Eleven patients ( 3 women, 8 men) with decompensated alcoholic cirrhosis of the liver with severe impairment of renal function and spironolacton-resistant ascites entered the study. They had been admitted to the intensive care unit because of deteriorating renal function despite volume expansion. The mean age was 48 years (38-58 years). All patients had impaired liver function: serum cholinesterase $<1.0 \mathrm{U} / \mathrm{L}$ (normal range, 2.2-3.8 U/L), prothrombin ratio $<0.45$ (of normal), bilirubin $>2.5 \mathrm{mg} / 100$ $\mathrm{mg}$, and albumin $<2.8 \mathrm{~g} / \mathrm{L}$. The impairment of renal function was indicated by a creatinine clearance below 40 $\mathrm{ml} \cdot \min ^{-1} \cdot 1.73 \mathrm{~m}^{-2}$ body surface area. The fractional elimination of sodium (FENa) was below $1 \%$ and all patients had ascites. Hypovolaemia was excluded by a central venous pressure $>5 \mathrm{~mm} \mathrm{Hg}$. Patients with severe imbalances of serum electrolytes did not participate in the study.
The serum concentrations of electrolytes before the onset of ornipressin infusion were potassium, $4.1 \pm 0.3$ and sodium, $135 \pm 3$ mval.

All patients received spironolactone $(100 \mathrm{mg}$ twice daily PO) for more than 4 weeks before admission to the hospital. Because of deterioration of renal function the dose was increased to $200 \mathrm{mg}$ IV twice daily, at least 5 days before the study and maintained during the study. None of the patients had received any additional diuretic therapy for at least 5 days. Nine patients improved during intensive care, two patients deteriorated, and finally died in coma. Liver cirrhosis was confirmed by biopsy or necropsy samples in all patients.

\section{Protocol of the Study}

The study was started at $8 \mathrm{AM}$ at least 24 hours after admission of the patient to the intensive care unit. After a 2-hour preperiod, ornipressin (POR 8; Sandoz, Bale, Switzerland) was continuously infused at a dose of $6 \mathrm{IU} / \mathrm{h}$ via a central venous catheter over a period of 4 hours, using an infusion pump (Perfusor; Braun Melsungen, Melsungen, Germany). This was followed by an observation period of 2 hours (postperiod). During the study, parenteral nutrition adapted for liver failure was continued (infusion rate: 1 $\mathrm{mL} \cdot \mathrm{kg}^{-1} \cdot \mathrm{h}^{-1}$, sodium $40 \mathrm{mmol} / \mathrm{L}$ ).

The study was performed according the principles of the declaration of Helsinki, and informed consent was obtained in every case. The consent form had been reviewed and approved by the Ethical Committee of the Department of Internal Medicine. If the patient was unable to understand the nature of the procedures, the family members were specifically informed.

\section{Clinical Tests}

Hemodynamic monitoring was performed using a femoral artery catheter and a percutaneously inserted $7 \mathrm{~F}$ flow-directed thermodilution pulmonary artery catheter (Gould SP 5507; Gould, Oxnard, CA). Cardiac output was estimated by the thermodilution technique with $10 \mathrm{ml}$ of a $5 \%$ solution of dextrose in water at $0^{\circ} \mathrm{C}$ (Gould Cardiac Output Computer). All measurements were performed in triplicate and averaged. The intravascular pressures were calibrated against a mercury sphygmomanometer and were recorded by Gould transducer SP50 (with the midaxillary line as zero reference) and a Hewlett-Packard multichannel recorder (Hewlett-Packard, Waltham, MA). The values were averaged at the end of exspiration for three successive respiratory cycles. Mean pressures were derived by electronic integration. Systemic vascular resistance was calculated from a standard formula (21). Hemodynamic data were recorded before the infusion of ornipressin, 2 and 4 hours after the start of the infusion and 2 hours after the end of the infusion.

Urine was collected via a transurethral catheter in 2-hour periods for measurement of urine osmolality and sodium and creatinine concentrations. Serum osmolality and sodium and creatinine concentrations were measured before and at the end of ornipressin infusion. The concentration of 
creatinine and sodium were determined by standard photometric methods (ACA, Wilmington, DE). The osmolality was measured by the freezing point method (Osmomat 030; Genotec, Berlin, Germany). Creatinine clearance, free water clearance and FENa were calculated using standard formulas (22).

Paraaminohippuric acid (PAH) and inulin clearance were determined according to standard methods in 8 patients. An IV loading dose of sodium PAH (Nephrotest; Lich, Hessen, Germany; $6 \mathrm{mg} / \mathrm{kg}$ ) or polyfructosan (inulin; Inutest, Laevosan, Linz, Austria; $30 \mathrm{mg} / \mathrm{kg}$ ) was followed by a continuous infusion at a rate of $30 \mathrm{~mL} / \mathrm{h}(\mathrm{PAH}, 22 \mathrm{mg} / \mathrm{mL}$; polyfructosan, $40 \mathrm{mg} / \mathrm{ml}$ ). Renal plasma flow and renal blood flow were calculated according to a standard formula (23). Renal fraction was determined by the ratio of cardiac output to renal blood flow. Filtration fraction was derived from the ratio of inulin clearance to renal plasma flow. Renal vascular resistance was calculated from the difference of mean arterial pressure and central venous pressure divided by the renal blood flow.

\section{Biochemical Analyses}

For analysis of the plasma level of noradrenaline, adrenaline and plasma renin activity arterial blood samples (femoral artery) in eight and nine patients, respectively, and for the determination of the ANF immunoreactivity, blood samples from the right atrium were collected in 10 patients before the start of the ornipressin infusion and 2 hours later into precooled heparinized tubes (for noradrenaline and adrenaline) and precooled tubes coated with sodium ethylenediaminetetraacetic acid (for ANF and plasma renin activity). Plasma was separated by centrifugation at $+2^{\circ} \mathrm{C}$ and stored at $-20^{\circ} \mathrm{C}$ until estimation.

Plasma levels of adrenaline and noradrenaline were analyzed after solvent extraction by high performance liquid chromatography with coulometric electrochemical detection (ESA Coulochem, Model 5100A; Bedford, MA). For the extraction of catecholamines from plasma (1-2 mL aliquots) the procedure described by Bauch et al. (24) with minor modifications was used. The concentration of tetraoctylammonium bromide in mixture $\mathrm{B}$ was reduced to 1.2 $\mathrm{mmol} / \mathrm{L}$. As an internal standard, $\alpha$-methyldopamine was added to the plasma sample before extraction. Chromato- graphic separation was achieved on a Nucleosil 5 SA column (130 × $4.6 \mathrm{~mm}$ ID; Macherey-Nagel, Düren, Germany). The mobile phase contained $100 \mathrm{mmol} / \mathrm{L}$ sodium acetate, $60 \mathrm{mmol} / \mathrm{L}$ sodium hydroxide, $40 \mathrm{mmol} / \mathrm{L}$ citric acid, and $10 \%$ methanol. The final $\mathrm{pH}$ was adjusted to 5.2 and the mobile phase was pumped at a flow rate of 1 $\mathrm{mL} / \mathrm{min}$. Plasma renin activity and ANF were measured by radioimmunoassays $(25,26)$.

\section{Data Analysis}

Data are expressed as mean values \pm SEM. Statistical analyses were carried out by means of analysis of variance followed by Tukey's studentized range test. For comparing two pairs of measures, the paired Student's $t$ test was applied. A significance level of $P<0.05$ was chosen.

\section{Results}

\section{Hemodynamic Changes}

The effect of ornipressin on various hemodynamic parameters is summarized in Table 1. Before the onset of ornipressin infusion a hyperdynamic circulatory state, characteristic for liver failure (2729), with increased cardiac output and decreased mean arterial pressure, was observed. These changes in systemic circulation were associated with a decrease in renal plasma flow and in renal fraction (proportion of cardiac output delivered to the kidney). During ornipressin infusion, the hypercirculatory state was reversed to an almost normal circulation accompanied by a significant increase in renal plasma flow and renal fraction. In addition, ornipressin caused a significant increase in pulmonary capillary wedge pressure, whereas the central venous pressure increased only slightly, without reaching the level of significance. The cardiovascular improvement presisted only as long as ornipressin was infused. In spite of a considerable increase of the lowered systemic vascular resistance from $545 \pm 39$ to $912 \pm 130$ dyne $\left.\mathrm{s}^{-1} \cdot \mathrm{cm}^{5} ; P<0.02\right)$ renal vascular resistance de-

Table 1. Hemodynamic Changes During Ornipressin Infusion

\begin{tabular}{|c|c|c|c|c|c|}
\hline & \multirow[b]{2}{*}{ Preperiod } & \multicolumn{2}{|c|}{ Ornipressin } & \multirow[b]{2}{*}{ Postperiod } & \multirow[b]{2}{*}{ Control values } \\
\hline & & +2 hours & +4 hours & & \\
\hline Heart rate (beats/min) & $104 \pm 4$ & $75 \pm 3^{a}$ & $76 \pm 4^{a}$ & $92 \pm 6$ & $78 \pm 4^{b}$ \\
\hline Pulmonary capillary wedge pressure $(\mathrm{mm} \mathrm{Hg})$ & $11 \pm 1$ & $14 \pm 1^{a}$ & $15 \pm 1^{a}$ & $9 \pm 1$ & $12 \pm 1^{b}$ \\
\hline Central venous pressure $(\mathrm{mm} \mathrm{Hg})$ & $8 \pm 1$ & $10 \pm 1$ & $10 \pm 1$ & $8 \pm 2$ & $6 \pm 1^{b}$ \\
\hline Mean arterial pressure $(\mathrm{mm} \mathrm{Hg})$ & $81 \pm 3$ & $100 \pm 4^{a}$ & $95 \pm 4^{a}$ & $77 \pm 4$ & $91 \pm 3^{b}$ \\
\hline Cardiac output $(\mathrm{L} / \mathrm{min})$ & $10.8 \pm 1.0$ & $8.4 \pm 0.7^{a}$ & $8.3 \pm 0.8^{a}$ & $10.0 \pm 0.8$ & $6.6 \pm 0.5^{b}$ \\
\hline Renal plasma flow $(\mathrm{mL} / \mathrm{min})$ & $195 \pm 40$ & $290 \pm 61^{a}$ & $273 \pm 38^{a}$ & $207 \pm 39$ & $574 \pm 35^{c}$ \\
\hline Renal fraction (of cardiac output) (\%) & $2.3 \pm 0.4$ & $4.7 \pm 1.0^{a}$ & $4.5 \pm 0.7^{a}$ & $3.0 \pm 0.5$ & $16 \pm 2^{c}$ \\
\hline
\end{tabular}

NOTE. $\mathrm{n}=11$.

${ }^{a} P<0.05$ vs. preperiod.

${ }^{b}$ Control values taken from Barrat-Boyes and Wood (57).

${ }^{c}$ Control values taken from Davies and Schock (58). 
Figure 1. Changes in renal and systemic vascular resistance in response to ornipressin infusion. The normal upper range of renal vascular resistance and the normal lower range of systemic vascular resistance are indicated as dotted lines.

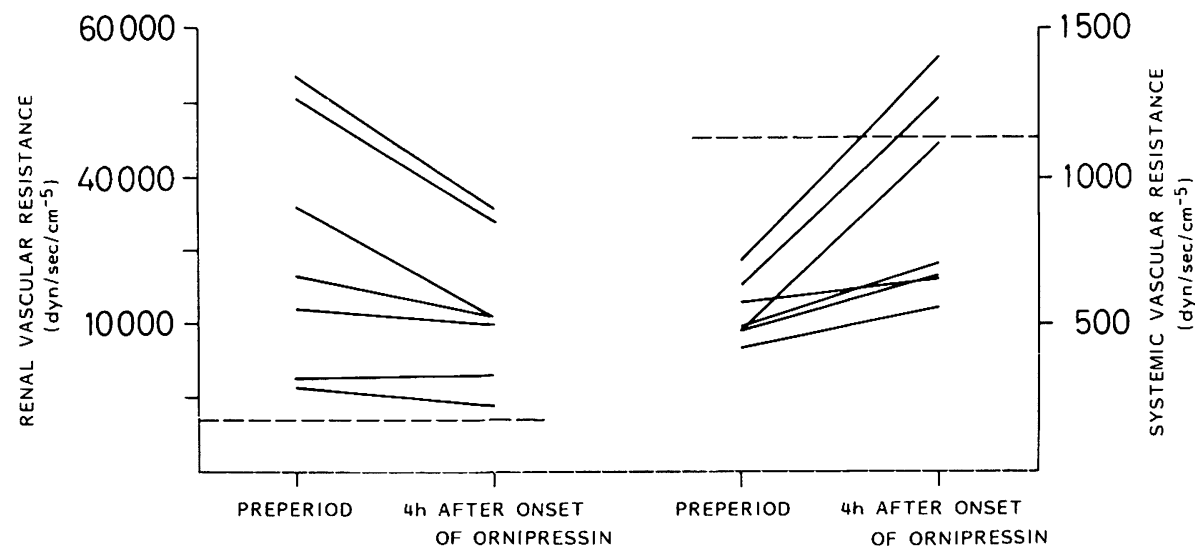

hours after onset of ornipressin infusion, respectively), inulin clearance $(18.6 \pm 2.6$ to $29.6 \pm 3.8$ and $31.6 \pm 3.9 \mathrm{~mL} / \mathrm{min})$, PAH clearance $(175 \pm 36$ to $261 \pm 54$ and $246 \pm 34 \mathrm{~mL} / \mathrm{min})$. Free water clearance decreased significantly from $-15 \pm 4$ to $-32 \pm 5$ $\mathrm{mL} / \mathrm{h}$ in the second 2 hour after onset of ornipressin infusion. In addition, a significant increase in $\mathrm{FENa}$ ( $0.46 \pm 0.10$ to $0.82 \pm 0.16$ and $1.3 \pm 0.27 \%)$, sodium excretion ( $1.91 \pm 0.65$ to $5.2 \pm 1.0$ and $8.5 \pm 2.8$ $\mathrm{mval} / 2 \mathrm{~h})$ and urine sodium concentration (16.6 \pm 3.4 to $27.0 \pm 6$ and $36.6 \pm 7.6 \mathrm{mval} / \mathrm{L}$ ) occurred in re-

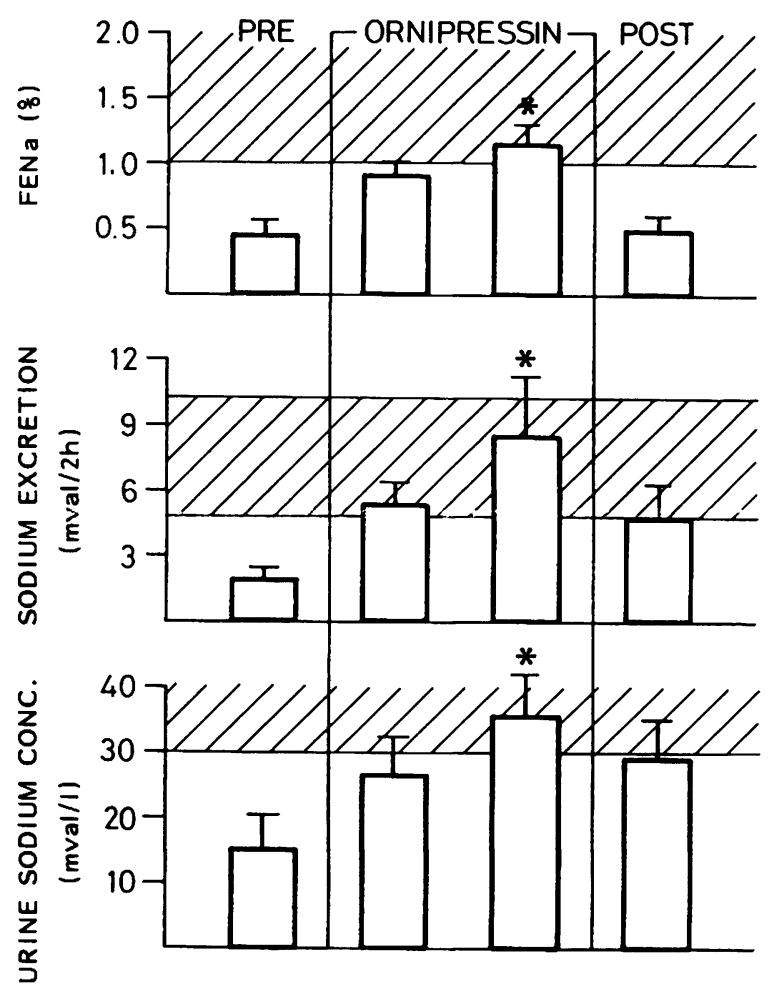

Figure 3. Effect of ornipressin infusion on urine sodium concentration, sodium excretion, and FENa. The parameters were measured or calculated from urine samples collected with 2 hours. The shaded areas indicate the normal range. ${ }^{*} P<0.05$ vs. preperiod $(n=11)$.
Figure 2. Effect of ornipressin infusion on PAH and inulin clearance. The clearances were measured from urine samples collected within 2 hours before, during, and after cessation of the ornipressin infusion. ${ }^{\star} P<0.05$ vs. preperiod $(n=8)$.

\section{Changes in Renal Function}

able improvement of renal function was achieved. The lowered creatinine clearance increased from $21 \pm$ 3 to $32 \pm 5 \mathrm{~mL}$ and $32 \pm 5 \mathrm{~mL} \cdot \mathrm{min}^{-1} \cdot 1.73 \mathrm{~m}^{-2}$ body surface area $(P<0.05), 2$ and 4 hours after onset of ornipressin infusion, respectively.

The changes of various parameters for renal funcare outlined in Figures 2 and 3. There was

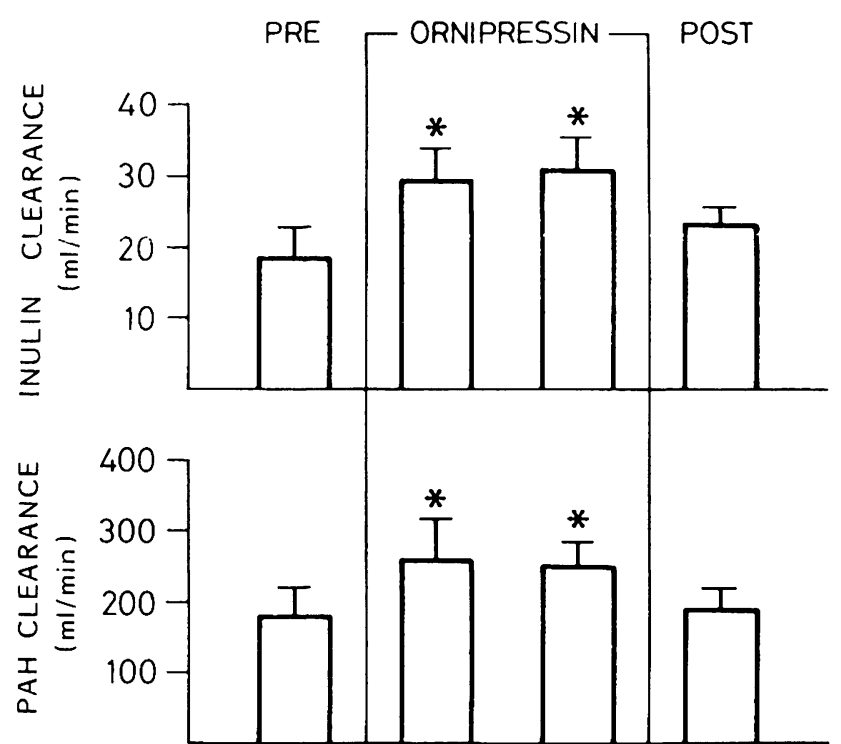
significant increase in urine volume (from 1.0 \pm 0.1 to $1.3 \pm 0.2$ and $1.6 \pm 0.3 \mathrm{~mL} / \mathrm{min}$ before and 2 and 4

creased during ornipressin infusion from $30308 \pm$ 6413 to $22153 \pm 3801$ dyne $\cdot \mathrm{s}^{-1} \cdot \mathrm{cm}^{5}(P<0.05$;
Figure 1). The decrease of renal vascular resistance was most pronounced in the patients with the highest 
sponse to ornipressin. After cessation of the infusion, renal function again deteriorated.

\section{Changes in Plasma Levels of Catecholamines, Renin Activity, and ANF}

The highly elevated plasma levels of noradrenaline and adrenaline decreased during the ornipressin administration [noradrenaline, from $2.08 \pm 0.30$ to $1.13 \pm 0.24 \mathrm{ng} / \mathrm{mL}(P<0.01)$; adrenaline, $0.86 \pm 0.32$ to $0.54 \pm 0.19 \mathrm{ng} / \mathrm{mL} ; P<0.05$ ]. The plasma renin activity declined from the initially high level of $27.6 \pm$ 5.1 to $14.2 \pm 4.0 \mathrm{ng} \cdot \mathrm{ml}^{-1} \cdot \mathrm{h}^{-1}(P<0.01)$. The atrial plasma level of ANF increased significantly from $33.5 \pm 5.2$ to $60.0 \pm 15.0 \mathrm{fmol} / \mathrm{mL}(P<0.02$; Figure $4)$.

As indicated in Figure 4, the decrease in the levels of noradrenaline, adrenaline, and plasma renin activity occurred uniformly in all patients, whereas a variable response was observed concerning ANF. The atrial level of ANF increased considerably during ornipressin infusion in seven patients, but slightly decreased in three patients. However, these three patients exhibited a similar response to ornipressin as the 7 patients with an increase in ANF with respect to the hemodynamic changes, the improvement of the renal function, and the decrease in plasma noradrenaline and renin activity.

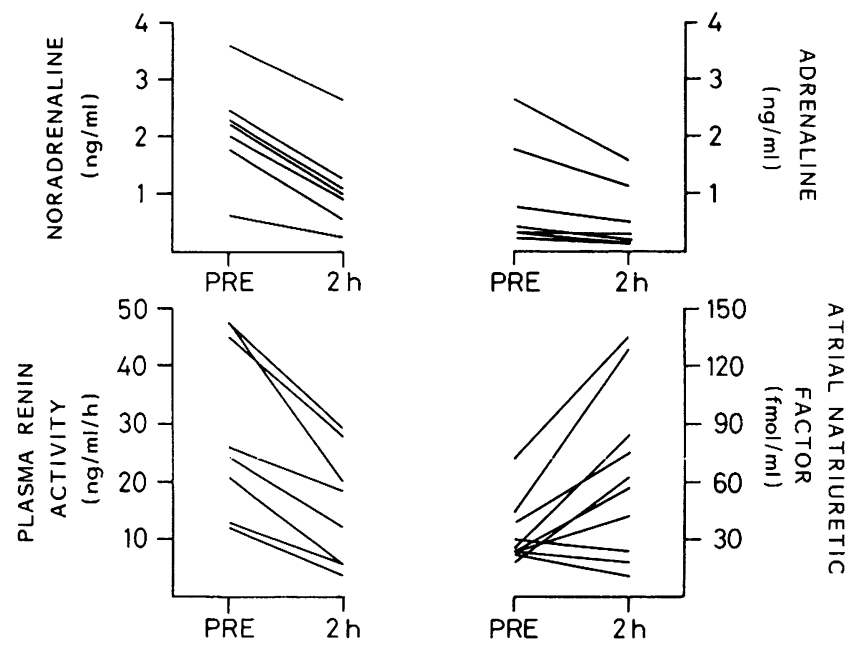

Figure 4. Individual changes in the arterial plasma levels of noradrenaline, adrenaline, and renin activity and in the atrial plasma level of ANF. Plasma samples were drawn immediately before and 2 hours after the onset of the ornipressin infusion. The mean levels of control subjects measured in our experimental conditions are noradrenaline, $0.26 \pm 0.04 \mathrm{ng} / \mathrm{mL}$; adrenaline, $0.05 \pm 0.01 \mathrm{ng} / \mathrm{mL} ;$ plasma renin activity, $1.58 \pm 0.32 \mathrm{ng} \cdot \mathrm{mL}^{-1}$. $\mathbf{h}^{-1}$. Control values for immunoreactive ANF in atrial plasma samples are not available for the antibody and experimental conditions used in the present investigation.

\section{Discussion}

The present investigation reinforces the beneficial effect of the vasopressin analogue ornipressin on renal dysfunction in patients with advanced liver cirrhosis. As described previously (7), creatinine clearance, urine volume, sodium excretion, and fractional elimination of sodium increased, whereas free water clearance decreased. In addition, we were able to demonstrate that glomerular filtration and renal blood flow improved considerably during the infusion of ornipressin. In line with these functional changes, an improvement of the renal hemodynamic situation was observed. The increase in systemic vascular resistance was counterbalanced by a decrease in renal vascular resistance. Subsequently, renal blood flow as well as the renal fraction of the cardiac output increased.

Various mechanisms may be involved in the beneficial effect of a vasoconstricting compound on renal function in advanced liver cirrhosis. The increase in mean arterial pressure during ornipressin infusion, at least partly, could be responsible for the improvement of renal function. However, not all changes in renal function can be explained sufficiently by the improvement in the systemic blood pressure. Data are available indicating that the increase of mean arterial pressure in cirrhotic patients during treatment with head-out water immersion and exogenous infusion of noradrenaline was not accompanied by significant changes in the clearance of creatinine, inulin, and $\mathrm{PAH}$, whereas sodium and water excretion significantly increased (9). Therefore, additional mechanisms appear to be of importance. One of the striking results in our investigation was the stimulation of ANF release in the majority of the patients, accompanied by a decrease in the plasma levels of catecholamines and plasma renin activity. Release of ANF into circulation is mainly stimulated by manipulations known to increase atrial pressure, such as acute volume expansion, water immersion, and vasoconstrictor substances $(30,31)$. In humans and rats, the administration of phenylephrine, vasopressin, or angiotensin II in hypertensive doses produce an immediate rise in ANF (32-34). Even increases in atrial pressure as small as $2 \mathrm{~mm} \mathrm{Hg}$ are sufficient to stimulate ANF secretion (33). In the present study, central venous pressure increased by about $2 \mathrm{~mm} \mathrm{Hg}$, representing an adequate stimulus. Various stimuli have been shown to stimulate the release of ANF in advanced liver cirrhosis, including volume expansion after peritoneovenous shunting $(35,36)$, head-out water immersion (37), and indirectly, large-volume paracentesis (38), but the extent of this release appears to be blunted (37). These findings indicate that in advanced liver cirrhosis the atrial pool of prohormone 
and/or releasable ANF and/or its synthesis rate may be diminished. Consequently, a prolonged stimulation of ANF release, as in the case of a 2-hour infusion period of ornipressin, may result in an attenuated amount of releasable ANF and may explain the decrease of ANF in some of the patients. Actually, in these patients the atrial level of ANF was in the lower range already before the onset of ornipressin infusion. Furthermore, other mechanisms have to be considered which influence ANF plasma concentrations, such as enzymatic degradation and clearance of the peptide from the circulation (39).

Whether the increased amount of circulating ANF could have contributed to the increase in natriuresis still remains a crucial question. Several pharmacological studies point to a reduced responsiveness to exogenous ANF in cirrhosis with ascites in humans and rats (40-43). The blunted renal response to ANF seems to be related to the altered systemic hemodynamics of cirrhosis and excessive antagonism by antinatriuretic factors, such as the renin-angiotensinaldosteron system. Because of its blood pressure lowering effect and hence further deterioration of the systemic hemodynamics, the therapeutic efficacy of exogenous ANF or a synthetic analogue has been shown to be limited in patients with cirrhosis complicated by renal dysfunction $(40,41,43,44)$. The important role of arterial hypotension in the diminished renal response to ANF has been shown in rats with $\mathrm{CCl}_{4}$-induced cirrhosis as well as in portal hypertensive rats, where the renal effects of ANF were enhanced on normalization of arterial pressure by either angiotensin II or ornipressin $(42,45)$. Furthermore, the blunted natriuretic response to ANF in chronic bileduct-ligated rats with cirrhosis and ascites has been reversed by bilateral renal denervation, indicating an involvement of increased renal sympathetic nerve activity in this phenomenon (46). Because a normalization of mean arterial pressure as well as an attenuation of the sympathetic nervous system activation was achieved during the infusion of ornipressin in the present study, the renal response to the increased plasma levels of endogenous ANF might have been preserved, and the increased release of ANF could have contributed to the enhanced natriuresis during ornipressin infusion. However, an impaired natriuretic response to ANF has been recently demonstrated in isolated perfused kidneys of rats with $\mathrm{CCl}_{4}$-induced cirrhosis (47).

A predominant effect of ornipressin in functional renal failure in liver cirrhosis is the escape from extreme renal vasoconstriction. The decrease in renal vascular resistance can be at least partly explained by the reduction in sympathetic nervous system activity and renin release in response to ornipressin as indicated by the considerable decrease in the plasma levels of noradrenaline and adrenaline and plasma renin activity. On the other hand a participation of ANF in this phenomenon might be expected. ANF has been shown to be a potent and relatively specific renal vasodilator substance $(48,49)$. The influence of this atrial peptide on renal hemodynamics seems to be unique as it causes a dilation of the blood vessels which supply the glomeruli and a vasoconstriction of the efferent arterioles (50) and, consequently, an increase of filtration fraction.

Recent findings point to the involvement of splanchnic vasodilation in the development of the functional renal failure in advanced cirrhosis. The systemic hyperdynamic circulatory status has been shown to be associated with a reduced flow to extrasplanchnic territories indicating a diversion of large fractions of the cardiac output from the vasoconstricted renal and femoral vascular beds to other vasodilated vascular beds, especially to the splanchnic area (16). The splanchnic vasodilation inspite of a considerably elevated sympathetic tone is probably related to the following phenomenon. During continued stimulation of sympathetic vasoconstrictor fibers to splanchnic vessels, an increase in intestinal blood flow occurs because of an autoregulatory escape (51). Therefore, the splanchnic vascular bed may not be sufficiently protected against the action of potent vasodilator compounds, which accumulate in liver failure $(12,17)$. As potent vasoconstrictor substances in the splanchnic area (18), vasopressin and its analogues with preferential vasoconstrictor action have the potential to counteract the profound vasodilation in the splanchnic beds. In addition, during ornipressin infusion, the vasoconstriction in renal and femoral beds was probably attenuated by reducing the extreme activation of the sympathetic nervous system. Thereby, the blood flow was shifted from splanchnic territories to extrasplanchnic areas as underlined by the increase in the renal fraction of the cardiac output.

One of the main factors responsible for the efficacy of ornipressin in improving renal function appears to be the suppression of the increased activity of the sympathetic nervous and of the renin-angiotensin systems. This pronounced suppression can be at least partly explained by the increase in mean arterial pressure, thereby altering the arterial baroreceptor response. On the other hand, ANF may contribute to this suppression, because ANF is known to inhibit renin release $(52,53)$ as well as sympatho-adrenal activity $(54,55)$.

In summary, the present results suggest the following mechanisms to be involved in the beneficial effect of ornipressin on renal failure associated with advanced liver cirrhosis. The improvement of renal hemodynamics as indicated by a decrease of renal vascular resistance and an increase of renal blood 
flow and of the renal fraction of cardiac output supposedly plays a key role. These changes appear to be linked to a shift of blood flow from splanchnic to extrasplanchnic territories, increase in mean arterial pressure, and to the suppression of the profound activation of the sympathetic nervous system and the renin-angiotensin axis. The contribution of ANF to this significant improvement is less defined. Because a variable response in the release of ANF occurred and the atrial plasma level of ANF even decreased in three patients, ANF is not necessarily a prerequisite for the observed changes.

The findings of the present investigation are of considerable clinical relevance. Treatment with ornipressin represents an alternative approach to the management of functional renal failure in advanced liver cirrhosis and might help to avoid or postpone the use of extracorporeal elimination techniques as an ultimate step. In cirrhotic patients, these procedures are afflicted with potential disadvantages, including dialysis-induced hypotension, increased risk of infection, worsening of coagulopathy, and changes in drug-protein binding (56). In addition, the use of ornipressin might be applied for optimizing the clinical condition of patients awaiting liver transplantation. This has been already demonstrated in a single patient (7). Further studies are in progress to evaluate the effect of long-term treatment with ornipressin.

\section{References}

1. Epstein M. Treatment of refractory ascites. N Engl J Med 1989;321:1675-1677.

2. Gornel DL, Lancestremere RG, Papper S, Lowenstein LM. Acute changes in renal excretion of water and solute in patients with Laemec's cirrhosis, induced by the administration of the pressor amine, metaraminol. J Clin Invest 1962;41: 94-603.

3. Lancestremere RG, Klingler EL, Frisch E, Papper S. Simultaneous determination of cardiac output and renal function in patients with Laemec's cirrhosis during the administration of the pressor amine, metaraminol. J Lab Clin Med 1963;61:820825.

4. Fischer JE, Baldessarini RJ. False neurotransmitters and hepatic failure. Lancet 1971;2:75-79.

5. Kew MC, Varma RR, Sampson DJ, Sherlock S. The effect of octapressin on renal and intrarenal blood flow in cirrhosis of the liver. Gut 1972;33:14-20.

6. Cohn JN, Tristani FE, Khatri IM. Systemic vasoconstrictor and renal vasodilator effects of PLV-2 (Octapressin) in man. Circulation 1968;38:151-157.

7. Lenz K, Druml W, Kleinberger G, Hörtnagl H, Laggner A, Schneeweiß B, Deutsch E. Enhancement of renal function with ornipressin in a patient with decompensated cirrhosis. Gut 1985;26:1385-1386.

8. Lenz K, Hörtnagl H, Druml W, Grimm G, Laggner A, Schneeweiß B, Kleinberger G. Beneficial effect of 8-ornithin vasopressin on renal dysfunction in decompensated cirrhosis. Gut 1989;30:90-96.

9. Shapiro MD, Nicholls KM, Groves BM, Kluge R, Chung HM, Bichet DG, Schrier RW. Interrelationship between cardiac output and vascular resistance as determinants of effective arterial blood volume in cirrhotic patients. Kidney Int 1985;28: 206-211.

10. Nicholls KM, Shapiro MD, Kluge R, Chung HM, Bichet DG, Schrier W. Sodium excretion in advanced cirrhosis: effects of expansion of central blood volume and suppression of plasma aldosterone. Hepatology 1986;6:235-238.

11. Epstein M, Berk DP, Hollenberg NK, Adams DF, Chalmers TC, Abrams HL, Merril JP. Renal failure in the patient with cirrhosis. The role of active vasoconstriction. Am J Med 1970;49:178-185.

12. Schrier RW, Arroyo V, Bernardi M, Epstein M, Henriksen JH, Rodés J. Peripheral arterial vasodilation hypothesis: a proposal for the initiation of renal sodium and water retention in cirrhosis. Hepatology 1988;8:1151-1157.

13. Solis-Herruzo A, Duran A, Favela V, Castellano G, Madrid JL, Munoz-Yaue MT, Morillas JD, Estenoz J. Effects of lumbar sympathetic block on kidney function in cirrhotic patients with hepatorenal syndrome. J Hepatol 1987;5:167-173.

14. Kotelanski B, Groszmann RJ, Cohn JN. Circulation times in the splanchnic and hepatic beds in alcoholic liver disease. Gastroenterology 1972;63:102-111.

15. Gerbes AL, Wernze H, Pilz A, Jüngst D, Arendt R. Effects of spironolactone and head-out water immersion on cirrhotic patients with and without ascites: evidence for the vasodilation hypothesis. Gastroenterology 1990;98:A588.

16. Fernandez-Seara J, Prieto J, Quiroga J, Zozaya JM, Cobos MA, Rodriguez-Eire JL, Garcia-Plaza A, Lela J. Systemic and regional hemodynamics in patients with liver cirrhosis and ascites with and without functional renal failure. Gastroenterology 1989;97:1304-1312.

17. Hörtnagl $H$, Singer EA, Lenz $K$, Kleinberger G, Lochs $H$. Substance $P$ is markedly increased in plasma of patients with hepatic coma. Lancet 1984;1:480-483.

18. Heyndrickx GR, Boettcher DH, Vatner SF. Effects of angiotensin, vasopressin, and methoxamine on cardiac function and blood flow distribution in conscious dogs. Am J Physiol 1976;231:1579-1587.

19. Schmid PG, Abboud FM, Wendling MG, Ramberg ES, Mark AL, Heistad DD, Eckstein JW. Regional vascular effects of vasopressin: plasma levels and circulatory responses. Am J Physiol 1974;227:998-1004.

20. Lenz K, Druml W, Hörtnagl H, Grimm G, Laggner A, Schneeweiß B, Schmid R. Improvement of renal haemodynamics in decompensated cirrhosis with ornipressin. J Hepatol 1989; 9(suppl 1):S181.

21. Barry WH, Grossman W. Cardiac catheterization. In: Braunwald E, ed. Heart disease. Philadelphia: Saunders, 1980:278307.

22. Ganong WF. Review of medical physiology. Los Altos, CA: Lange Medical, 1983:579.

23. Brenner B, Coe FL, Rector FC. Renal physiology in health and disease. Philadelphia: Saunders, 1987:24.

24. Bauch HJ, Kelsch U, Hauss WH. Einfache, schnelle, selektive und quantitative Bestimmung von Adrenalin und Noradrenalin im Plasma durch Kombination von Flüssigkeitsextraktion, HPLC-Trennung und elektro-chemische Detektion. J Clin Chem Clin Biochem 1986;24:651-658.

25. Haber E, Koerner T, Page LB, Burnode A. Application of a radioimmunoassay for angiotensin I to the physiological measurements of plasma renin activity in normal human subjects. J Clin Endocrinol Metab 1969;29:1349-1355.

26. Arendt RM, Gerbes AL, Ritter D, Stangl E. Molecular weight heterogeneity of plasma-ANF in cardiovascular diseases. Klin Wochenschr (suppl IV) 1986;64:97-102.

27. Murray JF, Dawson AM, Sherlock S. Circulatory changes in liver disease. Am J Med 1958;29:1349-1355. 
28. Kontos HA, Shapiro W, Mauck H, Patterson JL. General and regional alterations in cirrhosis of the liver. Am J Med 1963;37: 526-535.

29. Siegel JH, Goldwyn RM, Farrell E, Gallin P, Friedman HP. Hyperdynamic states and the physiological determinants of survival in patients with cirrhosis and portal hypertension. Arch Surg 1974;108:282-292.

30. Needleman P, Blaine EH, Greenwald JE, Michener ML, Saper CB, Stockman PT, Tolunay HE. The biochemical pharmacology of atrial peptides. Annu Rev Pharm Tox 1989;29:23-54.

31. Gerbes AL, Arendt RM, Paumgartner G. Editorial review: atrial natriuretic factor-possible implications in liver disease. J Hepatol 1987;5:123-132.

32. Manning PT, Schwartz D, Needleman P, Vasopressin-stimulated release of atriopeptin: endocrine antagonists in fluid homeostasis. Science 1985;229:395-397.

33. Schenker Y, Bates ER, Egan BH, Hammond J, Grekin RJ. Effect of vasopressors on atrial natriuretic factor and hemodynamic function in humans. Hypertension 1988;12:20-25.

34. Katsube N, Schwartz D, Needleman P. Release of atriopeptin in the rat by vasoconstrictors or water immersion correlates with changes in right atrial pressure. Biochem Biophys Res Comm 1985;133:937-944.

35. Wernze H, Burghardt W. Atrial natriuretic peptide, the sympathetic nervous system, and decompensated cirrhosis. Lancet 1986;1:331.

36. Klepetko W, Müller Ch, Hartter E, Miholic J, Schwarz Ch, Wolosczuk W, Moeschl P. Plasma atrial natriuretic factor in cirrhotic patients with ascites. Gastroenterology 1988;95:764770 .

37. Gerbes AL, Wernze H, Arendt RM, Riedel A, Sauerbruch T, Paumgartner G. Atrial natriuretic factor and renin-aldosterone in volume regulation of patients with cirrhosis. Hepatology 1989;9:417-422.

38. Salerno F, Badalamenti S, Moser P, Lorenzano E, Incerti P, Dioguardi N. Atrial natriuretic factor in cirrhotic patients with tense ascites. Effect of large-volume paracentesis. Gastroenterology 1990;98:1063-1070.

39. Gerbes AL, Vollmar AM. Degradation and clearance of atrial natriuretic factor. Life Sci 1990;47:1173-1180.

40. Salerno F, Badalementi S, Incerti P, Capozza L, Mainardi L. Renal response to atrial natriuretic peptide in patients with advanced liver cirrhosis. Hepatology 1988;8:21-26.

41. Petrillo A, Scherrer U, Gonvers JJ, Nussberger J, Marder H, deVane P, Welber B, Hofstetter JR, Brunner HR. Atrial natriuretic peptide administered as intravenous infusion or bolus injection to patients with liver cirrhosis and ascites. J Cardiovasc Pharmacol 1988;12:279-285.

42. López C, Jiménez W, Arroyo V, LaVilla G, Gaya J, Claria J, Rivera F, Rodes J. Role of altered systemic haemodynamics in the blunted renal response to atrial natriuretic peptide in rats with cirrhosis and ascites. J Hepatology 1989;9:217-226.

43. Fried T, Aronoff GR, Benabe JE, Brunner HR, DiBona GF, Fleischhauer T, Lam M, Lawton WJ, Luft FC, MartinezMaldonado M, McCullough A, Petrillo A. Renal and hemodynamic effects of atrial natriuretic peptide in patients with cirrhosis. Am J Med Sci 1990;299:2-9.

44. Fyrquist F, Totterman KJ, Tikkanen I. Infusion of atrial natri- uretic peptide in liver cirrhosis with ascites. Lancet 1985;2: 1439.

45. Ganger DN, Gottstein J, Blei AT. Hemodynamic and renal effects of atrial natriuretic factor in portal hypertensive rats. Potentiation by Phe-Ile-Orn-Vasopressin. J Pharmacol Exp Ther 1988;246:941-945.

46. Koepke JP, Jones S, DiBona GF. Renal nerves mediate blunted natriuresis to atrial natriuretic peptide in cirrhotic rats. Am J Physiol 1987;252:R1019-R1023.

47. Panos MZ, Gove C, Firth JD, Raine AEG, Ledingham JGG, Westaby D, Williams R. Impaired natriuretic response to atrial natriuretic peptide in the isolated kidney of rats with experimental cirrhosis. Clin Sci 1990;79:67-71.

48. Oshima T, Currie MG, Geller DM, Needlernan P. An atrial peptide is a potent renal vasodilator substance. Circ Res 1984;54:612-616.

49. Hintze TH, Currie MG, Needleman P. Atriopeptins: renal specific vasodilators in conscious dogs. Am J Physiol 1985;248: H587-H591.

50. Marin-Grez M, Fleming JT, Steinhausen M. Atrial natriuretic peptid causes pre-glomerular vasodilation and post-glomerular vasoconstriction in rat kidney. Nature 1986;324:473-476.

51. Granger DN, Richardson PDI, Kvietys PR, Mortillaro NA. Intestinal blood flow. Gastroenterology 1980;78:837-863.

52. Burnett JC Jr, Granger JP, Opgenroth TJ. Effects of synthetic atrial natriuretic factor in renal function and renin release. Am J Physiol 1984;247:F863-F866.

53. Heinrich WL, McAlister EA, Smith PB, Lipton J, Campbell WB. Direct inhibitory effect of atriopeptin III on renin release in primate kidney. Life Sci 1987;41:259-264.

54. Holtz J, Sommer O, Bassenge E. Inhibition of sympathoadrenal activity by atrial natriuretic factor in dogs. Hypertension 1987;9:350-354.

55. Richards AM, Ikram H, Yandle TG, Nicholls MG, Webster MWI, Espiner EA. Renal, haemodynamic, and hormonal effects of human alpha atrial natriuretic peptide in healthy volunteers. Lancet 1985;1:545-549.

56. Epstein M, Perez G, Oster JR. Management of renal complications of liver disease. J Intensive Care Med 1988;3:71-86.

57. Barratt-Boyes BG, Wood EH. Cardiac output and related measurements and pressure values in the right heart and associated vessels, together with the response to the inhalation of high oxygen mixtures in healthy subjects. J Lab Clin Med 1958;51: 72-90.

58. Davies DF, Schock NW. Age changes in glomerular filtration rate, effective renal plasma flow, and tubular excretory capacity in adult males. J Clin Invest 1950;29:496-507.

Received September 19, 1990. Accepted February 4, 1991.

Address requests for reprints to: Kurt Lenz, M.D., ICU, Med. Clin IV, University of Vienna, Währingergürtel 18-20, A-1090 Vienna, Austria.

Supported in part by DFG, grant Ge576.

The authors would like to thank C. Wolf for excellent technical assistance, W. Krivanek for superb secretarial help, and the nursing staff of the intensive care unit for helpful cooperation. 